\title{
The operator-early promoter regions of Shiga-toxin bearing phage $\mathrm{H}-19 \mathrm{~B}$
}

Ting Shi and David I. Friedman*

Department of Microbiology and Immunology, University of Michigan, Ann Arbor, MI 48109, USA.

\section{Summary}

Genes (stx) encoding Shiga toxins (Stx), major virulence factors in some pathogenic strains of Escherichia coli (STEC), are located in prophages of the $\lambda$ family. Agents that induce prophages lead to high levels of Stx, suggesting a role for the prophage in stx expression. Activation of the phage regulatory cascade has been shown to contribute to Stx production and release. Therefore, repressor-operator interactions that maintain prophage repression appear important in regulating expression of a major bacterial virulence factor. To determine if the operators of an stx-bearing phage have distinctive features, we characterized the operator regions of $\mathrm{H}-19 \mathrm{~B}$, a lambdoid phage carrying stx 1 genes. H-19B mutants that grow in the presence of repressor (classically called virulent mutants) were selected and the mutations definitively identified the operators. The $\mathrm{H}-19 \mathrm{~B}$ operators, as those in other lambdoid phages, comprise variations of an inverted repeat. Four repeats were identified in $O_{R}$ rather than the three found in each of the operators of other lambdoid phages. Primer extensions identified the transcription start sites of $P_{\mathrm{R}}$ and $P_{\mathrm{RM}}$, the two promoters in $\mathrm{O}_{\mathrm{R}}$ regulated by repressor.

\section{Introduction}

The stx genes, encoding Shiga toxins (Stx), are carried on resident prophages in some, if not all, of the strains of Escherichia coli that produce Stx (STEC) (O'Brien et al., 1984; Huang et al., 1987; Mizutani et al., 1999). One subset of STEC, enterohaemorrhagic E. coli (EHEC), has been identified as one of the newly emerging pathogens (Kaper and O'Brien, 1998). Because of the release of Stx, EHEC infections can result in serious sequelae such as haemorrhagic colitis and haemolytic uraemic syndrome, which are caused by Stx. All of the phages identified as

Accepted 26 April, 2001. *For correspondence. E-mail davidfri@ umich.edu; Tel. (+1) 734763 3142; Fax (+1) 7347643562. carriers of stx genes are members of the Lambda family of temperate phages (Karch et al., 1999; Mizutani et al., 1999).

For the most part, lambdoid phages share common regulatory schemes and genome arrangements. Genes having similar activities are located at analogous positions on the phage genomes, but genes having the same functional activity and genome position may have significant sequence differences. Highly conserved sequences scattered throughout these genomes allow recombination between the lambdoid phages, explaining why genome alignments reveal that the various lambdoid phage genomes appear to be mosaics generated by assortment from a common pool of genes (Susskind and Botstein, 1978; Campbell, 1988; Juhala et al., 2000).

After infection of an $E$. coli host, lambdoid phages can proceed via either the lysogenic or lytic pathway (Ptashne, 1992). Phages following the lysogenic pathway synthesize a limited number of functions that include repressor and integrase that turn off expression of most phage functions and integrate the phage DNA into the bacterial genome respectively. The integrated phage genome (the prophage) is thus replicated as a set of largely unexpressed genes on the bacterial chromosome. Phage following the lytic pathway express, in a regulated manner, functions required for replication, packaging and release of phage. The repressed prophage remains silent until the bacterial host existence is threatened by damage to its DNA; the resulting SOS response results in prophage induction (Little, 1995) and the induced prophage excises from the bacterial chromosome and enters the lytic pathway (Weisberg and Landy, 1983). Although $\lambda$ and its family of phages have served for decades as tools for studying major questions in molecular biology, only relatively recently has it been found that some members of this family of temperate phages contribute significantly to the virulence of pathogenic E. coli (reviewed in Waldor, 1998).

Shiga toxins (Stx) are a family of closely related toxins that were first identified in Shigella dysenteriae (reviewed in O'Brien and Holmes, 1987; 1996; Acheson et al., 1991). Stx are composed of two subunits, a single A subunit that disrupts protein synthesis in eukaryotic cells by cleaving the $28 \mathrm{~S}$ ribosomal RNA and a B subunit that forms a pentameric structure that facilitates entrance of the $A$ subunit into the eukaryotic cell. Two major groups of Stx are found in STEC, Stx 1 and Stx 2, which are related by 
varying similarities to the toxin found in $S$. dysenteriae. Analysis of the DNA sequences (Neely and Friedman, 1998a; Plunkett et al., 1999) of stx-carrying phages $\mathrm{H}-19 \mathrm{~B}$ (stx1) and $933 \mathrm{~W}$ (stx2) located the stx genes downstream of the phages' late $P_{\mathrm{R}}{ }^{\prime}$ promoters (Neely and Friedman, 1998b; Wagner et al., 2001) and upstream of the lysis genes (see Fig. 1). Subsequently, a search of stx and surrounding sequences indicated that, in all of the STEC strains examined, stx genes are carried either by complete or defective prophages (Mizutani et al., 1999; Unkmeir and Schmidt, 2000).

There are two primary ways induction of a prophage with stx genes located downstream of $P_{\mathrm{R}}{ }^{\prime}$ could lead to increased expression of $s t x$ genes. First, induction leads to replication of the prophage genome and, thus, to a significant increase in the copy number of the stx genes. Second, induction leads to transcription from phage promoters, including $P_{\mathrm{R}}{ }^{\prime}$. When RNA polymerase initiating transcription at $P_{\mathrm{R}}^{\prime}$ is modified by the $\mathrm{Q}$ gene product, there is high-level expression of downstream genes (see Fig. 1) (Roberts, 1992; Roberts et al., 1998), which would, when present, include the stx genes. Because of their location, the stx genes as well as the downstream phage lysis genes are part of the Q-dependent $P_{\mathrm{R}}$ ' transcription unit (Fig. 1) (Neely and Friedman, 1998b; Wagner et al. 2001). A number of studies have shown that treatment of STEC with agents that induce prophages result in production and release of high levels of Stx (Kimmitt et al., 1999; Matsushiro et al., 1999; Zhang et al., 2000).

Based on these considerations and experiments with phages that carry stx genes, we have proposed that significant levels of stx are expressed and/or released from a subpopulation of the bacteria in which the prophage has been induced (Neely and Friedman, 1998b; Wagner et al. 2001). In view of the fact that an apparent mechanism for Stx release could not be identified (O'Brien and Holmes, 1987), we additionally proposed that expression of phage encoded lysis functions after prophage induction could explain how Stx production and release might be coordinated. Therefore, the nature of the operator-repressor interaction is likely to be an important consideration in evaluating regulation of Stx production and release in STEC infections.

Based largely on studies with $\lambda$ (Ptashne, 1992), details of the design of lambdoid phage operator regions and the interactions of the operators with repressor have been elucidated. The $\lambda$ operator regions, located on either side of the $\mathrm{cl}$ (repressor) gene, regulate transcription initiating from the $P_{\mathrm{L}}$ and $P_{\mathrm{R}}$ promoters. Each operator region has three copies of variations of a 17 nucleotide sequence with partial dyad symmetry, and each of the $17 \mathrm{bp}$ sequences binds a dimer of repressor protein. Binding of repressor to the operator regions exhibits what is described as 'alternate pairwise cooperativity'; e.g. dimers at $\mathrm{O}_{\mathrm{R}} 1$ cooperatively bind with dimers at $\mathrm{O}_{\mathrm{R}} 2$. Dimers bound at $\mathrm{O}_{\mathrm{R}} 2$ cooperatively bind with dimers bound at $\mathrm{O}_{\mathrm{R}} 3$ when $\mathrm{O}_{\mathrm{R}} 1$ is mutationally inactivated. In addition to repressing transcription from $P_{\mathrm{R}}$, repressor also activates transcription from $P_{\mathrm{RM}}$, the promoter used for transcription of the $c$ l gene from the repressed prophage. Repressor bound at $\mathrm{O}_{\mathrm{R}} 2$ stimulates transcription of the $c$ l gene $P_{\mathrm{RM}}$. Thus, in the prophage state, repressor bound at $\mathrm{O}_{R} 1$ and $\mathrm{O}_{R} 2$ represses transcription of lytic genes expressed from $P_{\mathrm{R}}$ and activates transcription of the $\mathrm{cl}$ gene expressed from $P_{\mathrm{RM}}$ (Gussin et al., 1983; Ptashne, 1992).

In this study, we report results of genetic and biochemical experiments demonstrating that sites identified using sequence comparison with other lambdoid phages are the operators of $\mathrm{H}-19 \mathrm{~B}$; similarly the product of the $\mathrm{cl}$ gene is proven to encode the repressor protein. We find that the organization of the right operator region of $\mathrm{H}-19 \mathrm{~B}$ differs from that of $\lambda$, having four functional repressor binding sites in $\mathrm{O}_{R}$ rather than the three found in the $\lambda \mathrm{O}_{\mathrm{R}}$. Our studies also identify the $P_{\mathrm{R}}$ and $P_{\mathrm{RM}}$ promoters in the $\mathrm{H}-19 \mathrm{~B}$ immunity region.

\section{Results}

\section{Identification of operator sites and putative promoters}

Based on our sequence data (Neely and Friedman, 1998a) and the extensive information on the nature of operatorpromoter sites in other lambdoid phages (Ptashne, 1992), we identified sequences likely to be the $O_{L}$ and $O_{R}$ regions of $\mathrm{H}-19 \mathrm{~B}$ and the associated $P_{\mathrm{L}}$ and $P_{\mathrm{R}}$ promoters (Fig. 2A). These sites resemble operator regions found in other lambdoid phages in their locations relative to the $\mathrm{cl}$ gene, and in having variations of a consensus sequence (Fig. 2A and C) consisting of an inverted repeat of $17 \mathrm{bp}$ (as in the $\lambda$ operators) with partial dyad symmetries that are typically separated by seven or eight bp (Ptashne, 1992).

The $\mathrm{O}_{R}$ region of $\mathrm{H}-19 \mathrm{~B}$ (Fig. 2A), like those of $\lambda$ and other lambdoid phages (Fig. 2B) has three inverted repeats, corresponding to $\mathrm{O}_{R} 1, \mathrm{O}_{\mathrm{R}} 2$, and $\mathrm{O}_{\mathrm{R}} 3$, that are spaced, respectively, eight and seven nucleotides apart. However, a fourth site, $\mathrm{O}_{\mathrm{R}} \mathrm{O}$, having significant homology with the consensus $\mathrm{H}-19 \mathrm{~B}$ operator sequence, is located downstream of the putative $\mathrm{O}_{R} 1$. The one bp spacing between $O_{R} 1$ and $O_{R} 0$ is unusual. The $H-19 B O_{L}$ region has three repressor binding sites as does the $O_{L}$ of $\lambda$ and other lambdoid phages. It differs from $\lambda$ in the spacing between the $\mathrm{O}_{\mathrm{L}} 2$ and $\mathrm{O}_{\mathrm{L}} 3$ inverted repeats, $15 \mathrm{bp}$ in $\mathrm{H}-19 \mathrm{~B}$ rather than the $7 \mathrm{bp}$ in $\lambda$.

\section{Strategy for isolation of virulent mutants of $\mathrm{H}-19 \mathrm{~B}$}

The genetic identification of the operator regions of $\mathrm{H}-19 \mathrm{~B}$ 


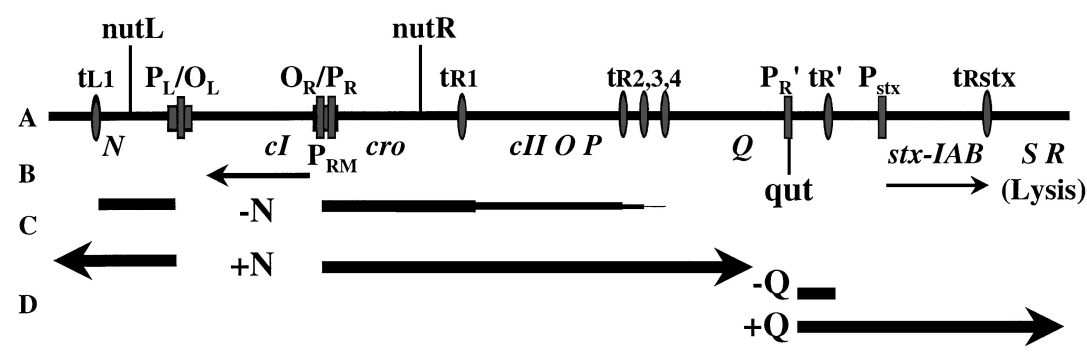

Fig. 1. Arrangement of regulatory signals, genes, and transcription patterns in the early region of $\mathrm{H}-19 \mathrm{~B}$.

A. Above and within the line are shown locations of promoter, operators, nut, qut, and transcription terminators. Below the line are shown the locations of relevant genes.

B. Transcription from the $P_{\mathrm{RM}}$ promoter, which is responsible for expression of maintenance levels of repressor protein and $P_{\mathrm{STX}}$.

C. Transcription from early $P_{\mathrm{L}}$ and $P_{\mathrm{R}}$ promoters in the presence and absence of $\mathrm{N}$. The change in the thickness of the line indicates different levels of readthrough of transcription terminators.

D. Transcription from $P_{\mathrm{R}}{ }^{\prime}$ in the presence and absence of $\mathrm{Q}$.

A

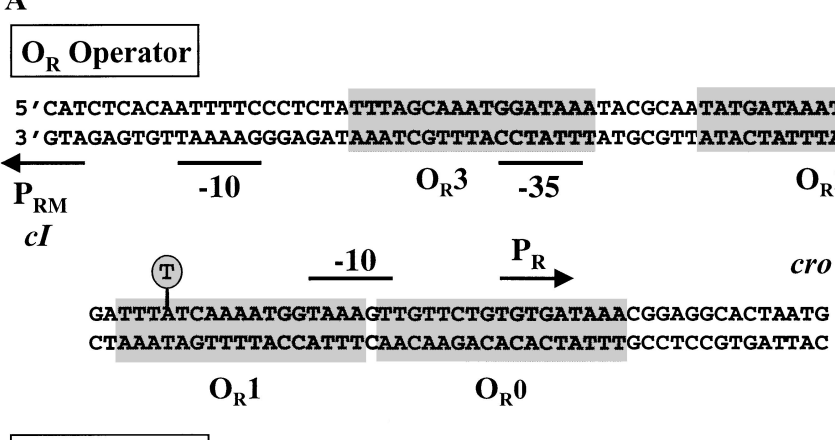

$\mathbf{O}_{\mathrm{L}}$ Operator

5 ' TGGGTGAACTTTATCGGAATGATAAATTAATGGCAATAGCAAAATGATAAATTCTCTTGGTT

3' ACCCACTTGAAATAGCCTIACTTATTTAATTACCGTTATCGTTTTACTATPTAAGAGAACCAA

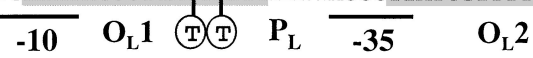

TTCAAATATCGTATTGATTCTTATGGTGTT AAGTTTATAGCATAACTAAGAATACCACAA

$\mathrm{O}_{\mathrm{L}} 3(?)$

B

Left Operator

Lambda

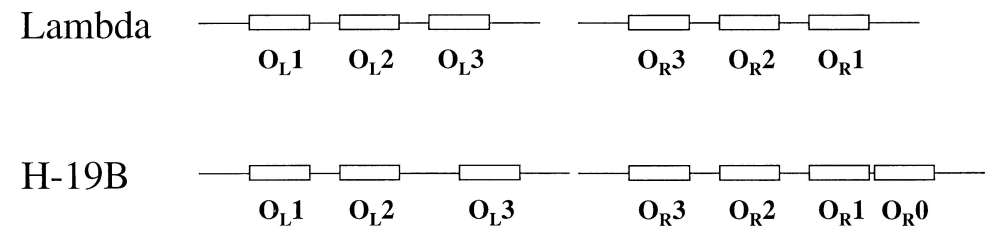

C

$-35$

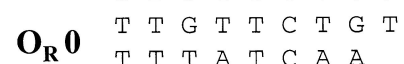

$\mathbf{O}_{\mathbf{R}} \mathbf{1}$ T

$\begin{array}{llllllllll}\mathbf{O}_{\mathbf{R}} \mathbf{2} & \text { T } & \text { A } & \text { T } & G & A & \text { T } & A & A & A \\ & \text { A } & \text { A } & \text { T } & G & \text { T } & \text { A } & \text { A } & \text { A }\end{array}$

$\mathbf{O}_{\mathbf{R}} \mathbf{3}$ T

$\begin{array}{lllllllllll} & \mathbf{O}_{\mathbf{L}} \mathbf{1} & \text { T } & \text { T } & \text { T } & \text { A } & \text { T } & C & G & G & A \\ & \text { T } & \text { T } & \text { T } & \text { A } & \text { T } & \text { C } & \text { A } & \text { T }\end{array}$

$\mathbf{O}_{\mathrm{L}} 2$ A A $\mathrm{T}$ A $G$ C A A A

$\mathbf{O}_{\mathbf{L}} \mathbf{2}$ T $T$ T T A T C A T

$\mathbf{O}_{\mathbf{L}} \mathbf{3} \begin{array}{lllllllll}\text { A } & \text { A } & \text { T } & A & T & C & G & T & A \\ \text { A } & G & A & A & T & C & A & A\end{array}$

Consensus T T T A T C A A A

Fig. 2. A. Left and right operator sequences of $\mathrm{H}-19 \mathrm{~B}$. Highlighted are the imperfect inverted repeats corresponding to the consensus operator sequence that were definitively identified by DNase I protection studies. The arrows indicate the transcription start sites of the $P_{\mathrm{RM}}$ and $P_{\mathrm{R}}$ transcripts and point in the direction of transcription. The putative -10 and -35 regions of the $P_{\mathrm{RM}}$ and $P_{\mathrm{R}}$ promoters are indicated above and below the DNA sequence respectively. Nucleotide changes in the operators found in the $\mathrm{H}-19 \mathrm{Bvir}$ mutant are placed above and below the wild-type sequence. B. Diagram showing the relative positions of the operator binding sites in the $\lambda$ and $\mathrm{H}-19 \mathrm{~B}$ operators.

C. Alignment of $\mathrm{H}-19 B$ operator half-sites. The upper sequences are from the left half of the upper strands and the lower sequences are from the right half of the lower strands. Shown at the bottom is the derived consensus operator site sequence. 
was based on the studies that identified the operators of $\lambda$ (reviewed in Ptashne et al., 1980; Gussin et al., 1983; Ptashne, 1971; 1992). In those classic studies, a $\lambda$ mutant that grew in the presence of repressor was isolated as a variant that formed plaques on a lawn of a $\lambda$ lysogen (Jacob and Wollman, 1954). Subsequently, it was shown that this mutant, called virulent (vir), had mutations in sites (operators) on either side of the $c$ l gene. It should be noted that this use of the term virulent (as well as the term virulence) should be distinguished from its use to describe the pathogenic nature of infectious bacteria. Hopkins and Ptashne (1971) determined that three of the four mutations initially identified in this virulent mutant were necessary for virulence. The mutations, two in $\mathrm{O}_{\mathrm{R}}$ and one in $\mathrm{O}_{\mathrm{L}}$, reduce repressor binding at those sites and thus permit sufficient transcription from $P_{\mathrm{R}}$ and $P_{\mathrm{L}}$ in the presence of repressor to support phage growth. Transcription from $P_{\mathrm{R}}$ is required for expression of nearly all genes whose products are involved in lytic growth, whereas transcription from $P_{\mathrm{L}}$ is required for expression of $\mathrm{N}$, which is required for transcription initiating at $P_{\mathrm{R}}$ to proceed through transcription terminators into downstream genes (Fig. 1). Because $\mathrm{H}-19 \mathrm{~B}$ has a gene arrangement in this region similar to that of $\lambda$ (Neely and Friedman, 1998a), we adopted a working model that $\mathrm{H}-19 \mathrm{~B}$ virulent mutants would require at least two mutations reducing repressor binding, one in $\mathrm{O}_{\mathrm{R}}$ and one in $\mathrm{O}_{\mathrm{L}}$. Based on these assumptions, we used a twostep strategy for isolating virulent mutants of $\mathrm{H}-19 \mathrm{~B}$; selecting first for a mutation(s) in $\mathrm{O}_{R}$ and then for a mutation(s) in $\mathrm{O}_{\mathrm{L}}$.

\section{Isolation of virulent mutants of $\mathrm{H}-19 B$}

In selecting mutations affecting repressor binding at $\mathrm{O}_{R}$, we assumed that, as in $\lambda$, the only function expressed from $P_{\mathrm{L}}$ required for $\mathrm{H}-19 \mathrm{~B}$ lytic growth would be $\mathrm{N}$ (Court and Sato, 1969; Sly et al., 1971). The selecting bacterium, $\mathrm{K} 9368$, has an $\mathrm{H}-19 \mathrm{~B}$ prophage that blocks growth of an infecting $\mathrm{H}-19 \mathrm{~B}$ and, because it carries the plac- $\mathrm{N}(\mathrm{H}-19 \mathrm{~B})$ plasmid, constitutively expresses $\mathrm{H}-19 \mathrm{~B} \mathrm{~N}$. If our assumption that transcription from $P_{\mathrm{L}}$ is only needed to supply $\mathrm{N}$ is correct, then an $\mathrm{H}-19 \mathrm{~B}$ variant with a mutation reducing binding of repressor at $\mathrm{O}_{\mathrm{R}}$, thus freeing $P_{\mathrm{R}}$ from repressor control, should grow in K9368. Although repressor will bind at $\mathrm{O}_{\mathrm{L}}$ and block transcription from $P_{\mathrm{L}}$, the $\mathrm{N}$ supplied from the plasmid will obviate the need for $P_{\mathrm{L}}$ transcription. A directed mutagenesis strategy was used to create a pool of $\mathrm{H}-19 \mathrm{~B}$ enriched for mutations in the $\mathrm{O}_{R}$ region (see Experimental procedures). This pool was used to isolate an $\mathrm{H}-19 \mathrm{~B}$ derivative that forms plaques on a lawn of K9368. As expected, this mutant phage is not fully virulent because it is unable to form plaques on $\mathrm{K} 7523$, an $\mathrm{H}-19 \mathrm{~B}$ lysogen that does not provide $\mathrm{H}-19 \mathrm{~B}$ $N$. DNA sequencing of the immunity region revealed that this partially virulent phage has a single mutation in $\mathrm{O}_{\mathrm{R}} 1$ (see Fig. 2A). The mutation, an AT to TA transversion in the fourth position, was named $\mathrm{O}_{\mathrm{R}} 1 \mathrm{~A} 4 \mathrm{~T}$. The phage carrying the $\mathrm{O}_{R} 1 \mathrm{~A} 4 \mathrm{~T}$ mutation was named $\mathrm{H}-1$ - BvirR-1.

To begin the selection for full virulence, H-19BvirR-1 was grown in the mutD5 (Fowler et al., 1974) strain, $\mathrm{K} 7045$. The resulting mutagenized lysate was used to obtain fully virulent $\mathrm{H}-19 \mathrm{~B}$ by selecting for derivatives of $\mathrm{H}-19 B$ virR-1 that form plaques on an $\mathrm{H}-19 \mathrm{~B}$ lysogen, $\mathrm{K} 7523$. DNA sequencing of the operator region revealed that in addition to the $\mathrm{O}_{\mathrm{R}} 1 \mathrm{~A} 4 \mathrm{~T}$ mutation identified in $\mathrm{H}-19 \mathrm{BvirR}-1$, this fully virulent phage has two mutations in $\mathrm{O}_{\mathrm{L}} 1$ (see Fig. 2A). The changes are an AT to TA transversion at position four (the same as the $\mathrm{O}_{R} 1 A 4 T$ mutation) and a CG to TA transition at position six. These mutations were named, respectively, $\mathrm{O}_{\mathrm{L}} 1 \mathrm{~A} 4 \mathrm{~T}$ and $\mathrm{O}_{\mathrm{L}} 1 \mathrm{C6T}$.

We next considered whether the acquisition of the two mutations in $\mathrm{O}_{\mathrm{L}}$ was fortuitous or was required for full virulence. Using site-directed mutagenesis, we constructed derivatives of $\mathrm{H}-19 B$ BirR-1 that contained either $\mathrm{O}_{\mathrm{L}} 1 \mathrm{~A} 4 \mathrm{~T}$ or $\mathrm{O}_{\mathrm{L}} 1 \mathrm{C6T}$ (see Experimental procedures). As shown in Table 1, a fully virulent derivative could be constructed from $\mathrm{H}-19 \mathrm{BvirR}-1$ that also carried either of the two changes in $\mathrm{O}_{\mathrm{L}}$ found in the original fully virulent mutant. $\mathrm{H}-19 \mathrm{~B}$, unlike the classical $\lambda$ virulent mutant

Table 1. Plating of $\mathrm{H}-19 \mathrm{~B}$ virulent mutants and effectiveness of $\mathrm{H}-19 \mathrm{~B} \mathrm{Cl}$ proteins.

\begin{tabular}{|c|c|c|c|c|c|}
\hline \multirow[b]{2}{*}{ Strain } & \multirow{2}{*}{$\begin{array}{l}\text { Bacteria } \\
\text { Source of } \mathrm{H}-19 \mathrm{~B} \mathrm{Cl}\end{array}$} & \multicolumn{4}{|c|}{ Efficiency of plating of listed phages } \\
\hline & & $\mathrm{H}-19 \mathrm{~B}$ & $\mathrm{H}-19 \mathrm{Bvir}^{\mathrm{a}}$ & $\mathrm{H}-19 \mathrm{Bvir} 1^{\mathrm{b}}$ & H-19Bvir2 ${ }^{C}$ \\
\hline K3443 & No $\mathrm{Cl}$ & 1 & 1 & 1 & 1 \\
\hline $\mathrm{K} 9866^{\mathrm{d}}$ & H-19B Prophage & $<10^{-7}$ & 1 & 1 & 1 \\
\hline$K 9153^{d}$ & Cloned $\mathrm{H}-19 \mathrm{~B}$ cltrc $^{\mathrm{e}}$ & $<10^{-7}$ & 1 & 1 & 1 \\
\hline $\mathrm{K} 9710^{\mathrm{d}}$ & Cloned $\mathrm{H}-19 \mathrm{~B} c^{\mathrm{e}}$ & $<10^{-7}$ & 1 & 1 & 1 \\
\hline
\end{tabular}

a. Virulent mutant with oR1A4T, oL1A4T, and oL1C6T mutations.

b. Virulent mutant with oR1A4T and oL1A4T mutations.

c. Virulent mutant with oR1A4T and oL1C6T mutations.

d. Isogenic with K3443 except for indicated added genome.

e. Expressed $\mathrm{Cl}$ proteins were His tagged. 
(Hopkins and Ptashne, 1971), only requires two mutations for virulence, one in $\mathrm{O}_{\mathrm{L}} 1$ and one in $\mathrm{O}_{\mathrm{R}} 1$.

\section{Cloning and expression of the $\mathrm{H}-19 \mathrm{~B}$ full size and a truncated repressor}

The $\mathrm{H}$-19B cl-repressor gene was cloned in an expression vector so that the expressed $\mathrm{Cl}$ protein has a polyhistidine tail that facilitates isolation of repressor. Previous work from this laboratory, using fragments from the $\mathrm{H}-19 \mathrm{~B}$ genome cloned into a plasmid vector, identified a $4.3 \mathrm{~kb}$ fragment that conferred the same immunity characteristics as an $\mathrm{H}-19 \mathrm{~B}$ prophage (Neely and Friedman, 1998a). Escherichia colicarrying the plasmid with this fragment are immune to infection with $\mathrm{H}-19 \mathrm{~B}$, but do support growth of other lambdoid phages. Based on this result, we identified the putative gene encoding the $\mathrm{H}-19 \mathrm{~B} \mathrm{Cl}$ repressor and cloned the putative $\mathrm{cl}$ gene downstream of the T5 promoter and in-frame with a sequence encoding a poly histidine tail in pQE-60 generating plasmid pQE-H19Bcl. An $\mathrm{H}-19 \mathrm{~B} \mathrm{cl}$ gene truncated at the $3^{\prime}$ end was similarly cloned in pQE-60 generating pQE-H-19Bcltrc. The expressed truncated repressor protein, $\mathrm{Cl}$-trc, is missing the 55 carboxy-terminal amino acids of the full sized repressor protein. This protein was produced to assess the functional role of the carboxy portion of the $\mathrm{Cl}$ protein.

Escherichia coli derivatives carrying plasmids expressing either the full-sized or truncated $\mathrm{Cl}$ protein fail to support growth of infecting $\mathrm{H}-19 \mathrm{~B}$, showing that the Histag does not substantially interfere with the biological activity of either of these $\mathrm{H}-19 \mathrm{~B}$ repressor proteins, and that the truncated $\mathrm{Cl}$ protein is functional (Table 1). The fact that the truncated protein has repressor activity indicates that, like repressors of other lambdoid phages (Ptashne, 1992), the DNA binding domain of the $\mathrm{H}-19 \mathrm{~B}$ repressor is probably located in the amino portion of the repressor protein.

\section{Gel mobility shifts with $O_{R} D N A$}

Gel mobility shift assays with full-size repressor protein demonstrate that $\mathrm{H}-19 \mathrm{~B}$ repressor binds to the region of the $\mathrm{H}-19 \mathrm{~B}$ genome identified by sequence analysis as the right operator and the site is specific for that protein (Fig. 3A). Lanes 1-6 show gel mobility shifts with a labelled $240 \mathrm{bp}$ fragment containing the four putative $\mathrm{O}_{R}$ operator sites from a wild-type operator. With increasing concentrations of repressor, bands are observed at three positions. Although the identification of bands at three positions in the gel is consistent with three operator sites in $\mathrm{O}_{\mathrm{R}}$, we show below in the footprint analysis that there is a fourth potential repressor binding site in $\mathrm{O}_{\mathrm{R}}$. Presumably, the strength of binding at this site is insufficient to be maintained during electrophoresis.

Gel mobility shift assays were also used to examine binding of repressor to a variant of the $\mathrm{O}_{R}$ DNA fragment with the $\mathrm{O}_{R} 1 \mathrm{~A} 4 \mathrm{~T}$ mutation identified in the $\mathrm{H}-19 \mathrm{~B}$ virulent mutant described above. A higher concentration of repressor is required to shift the mutant probe, suggesting that the $\mathrm{O}_{R} 1 \mathrm{~A} 4 \mathrm{~T}$ mutation reduces the affinity of $\mathrm{O}_{R}$ for repressor (compare lanes 2, 3 and 4 with 10, 11 and 12). The gel mobility shifts also indicate another way that binding to the mutant probe differs from binding to the wildtype probe. At low repressor concentration, a single band is observed initially at position 1 (lanes 11 and 12) and at higher concentrations bands are observed at positions 1 and 3 , but not at position 2 (lanes 13 and 14). This suggests that even though binding at $\mathrm{O}_{R} 1$ is weakened by the $\mathrm{O}_{R} 1 \mathrm{~A} 4 \mathrm{~T}$ mutation, at higher repressor concentrations either the mutant $\mathrm{O}_{R} 1$ or the putative fourth $\mathrm{O}_{R}$ site, $\mathrm{O}_{R} 0$ participates in binding of repressor.

To determine if binding at $\mathrm{O}_{R}$ is specific for the $\mathrm{H}-19 \mathrm{~B} \mathrm{Cl}$ protein, we determined if two other proteins, $\lambda$ repressor (lane 7) and BSA (lane 8), would shift the probe. Both of these proteins failed to shift any of the probe. Therefore, we concluded that the $\mathrm{H}-19 \mathrm{~B} \mathrm{O}_{\mathrm{R}}$ region specifically interacts with $\mathrm{H}-19 \mathrm{~B}$ repressor.

\section{Gel mobility shifts with $O_{L} D N A$}

Gel mobility shift assays demonstrate that the region of the $\mathrm{H}-19 \mathrm{~B}$ genome identified using sequence analysis as the left operator specifically binds $\mathrm{H}-19 \mathrm{~B}$ repressor (Fig. 3B). Lanes 1-6 show band shifts with a labelled $200 \mathrm{bp}$ fragment containing wild-type $\mathrm{O}_{\mathrm{L}}$ operator sites in the presence of twofold increases in repressor concentration. Two bands are observable suggesting that $O_{L}$ has two binding sites. However, as discussed below, the DNase I protection studies are consistent with a third operator site in $\mathrm{O}_{\mathrm{L}}$. As was discussed above for the fourth site in $\mathrm{O}_{R}$, we assume the strength at the third site in $\mathrm{O}_{\mathrm{L}}$ of binding is insufficient to be maintained during electrophoresis.

Lanes 9-14 show gel mobility shifts with an $O_{L}$ variant probe that is identical to the wild-type $\mathrm{O}_{\mathrm{L}}$ probe used above except that it contains the $\mathrm{O}_{\mathrm{L}} 1 \mathrm{~A} 4 \mathrm{~T}$ and $\mathrm{O}_{\mathrm{L}} 1 \mathrm{C} 6 \mathrm{~T}$ mutations identified in the $\mathrm{H}-19 \mathrm{Bvir}$ mutant described above. Only one band is observed, even at repressor concentrations that shifts all of the probe. This suggests that the $\mathrm{O}_{L}$ mutations eliminate binding at $\mathrm{O}_{\mathrm{L}} 1$. Moreover, the repressor concentrations required to shift the mutant probe are slightly higher than those required to shift the wild-type probe. This data also suggests that $O_{L}$ has two repressor binding sites rather than the three predicted by the sequence analysis. However, as reported below, the DNase I protection studies provide evidence that there are three repressor binding sites in the $\mathrm{H}-19 \mathrm{~B} \mathrm{O}_{\mathrm{L}}$ region. 


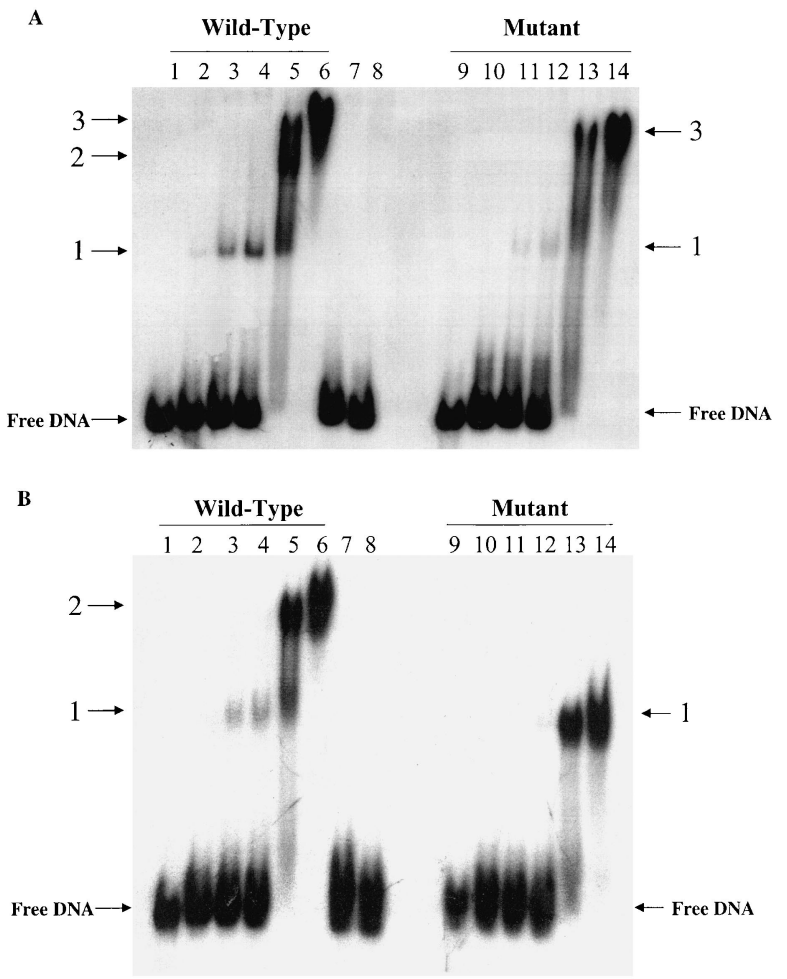

Fig. 3. Binding of $\mathrm{H}-19 \mathrm{~B}$ repressor to operator sites as assessed using gel mobility shifts. DNA fragments containing either the $\mathrm{O}_{R}$ or $\mathrm{O}_{L}$ sites were end labelled with ${ }^{32} \mathrm{P}$ and incubated in the absence of repressor with twofold increases of concentrations $(60,220,450,900$ and $1800 \mathrm{nM}$ ) of $\mathrm{H}-19 \mathrm{~B}$ repressor or with control proteins (1500 nM). Reaction mixtures were analysed using electrophoresis in a nondenaturing polyacrylamide gel (see Experimental procedures for details). Arrows indicate positions of bands.

A. Probes were DNA fragments containing the $\mathrm{O}_{R}$ or a variation of the $\mathrm{O}_{R}$ sequence. The probe used in gel shifts shown in lanes 1-6 had the wild-type $\mathrm{O}_{R}$ sequence and the probe used in gel shifts shown in lanes $9-14$ had a variant $O_{R}$ sequence with the $O_{R} 1 A 4 T$ mutation. Proteins used in gel shifts: lanes $2-6$ and $10-14, \mathrm{H}-19 \mathrm{~B}$ repressor; lane $7, \lambda$ repressor; lane $8, \mathrm{BSA}$. Lanes 1 and 9, DNA probe incubated in the absence of protein.

B. Probes were DNA fragments containing the $\mathrm{O}_{L}$ sequence or a variation of the $O_{L}$ sequence. The probe used in gel shifts shown in lanes 1-6 had the wild-type $O_{L}$ sequence and the probe used in gel shifts shown in lanes 9-14 had a variant $O_{L}$ sequence with the $\mathrm{O}_{\mathrm{L}} 1 \mathrm{~A} 4 \mathrm{~T}$ and $\mathrm{O}_{\mathrm{L}} 1 \mathrm{C} 6 \mathrm{~T}$ mutations. Proteins used in gel shifts: lanes 2-6 and $10-14, \mathrm{H}-19 \mathrm{~B}$ repressor; lane $7, \lambda$ repressor; lane $8, \mathrm{BSA}$. Lanes 1 and 9, DNA probe incubated in the absence of protein.

\section{DNase I protection of $O_{R}$}

The nature of the repressor binding sites in the $\mathrm{H}-19 \mathrm{~B} \mathrm{O}_{R}$ region was examined by DNase I protection using purified His-tagged $\mathrm{H}-19 \mathrm{~B}$ repressor and $240 \mathrm{bp}{ }^{32} \mathrm{P}$-labelled DNA fragments containing either the wild-type or the $O_{R} 1 A-T$ mutant $\mathrm{O}_{\mathrm{R}}$ regions.

Looking at protection of the top strand (Fig. 4A, lanes 17 ), the protected regions correspond to at least three operator sites as suggested by the gel mobility shift experiments, with a suggestion of protection above the $\mathrm{O}_{R} 1$ site, which we call $\mathrm{O}_{R} 0$ (see section below). However, because these sequences are located in the compressed part of the gel, it is not possible to assess the significance of this protection. Although there appears to be better protection of $\mathrm{O}_{R} 1$ and $\mathrm{O}_{\mathrm{R}} 2$ at lower repressor concentrations than $\mathrm{O}_{\mathrm{R}} 3$, effective protection of $\mathrm{O}_{\mathrm{R}} 3$ requires, at most, a twofold higher concentration of repressor for protection (compare lanes 3 and 4).

A different DNase I protection pattern was observed with a labelled mutant DNA fragment with the $O_{R} 1 A-T$ vir mutation (Fig. 4A, lanes 8-14). Looking at protection of the top strand, there is, as expected, reduced protection of $\mathrm{O}_{\mathrm{R}} 1$. The protection at $\mathrm{O}_{\mathrm{R}} 2$ does not appear to be different from that seen with the wild-type fragment, whereas protection at $\mathrm{O}_{\mathrm{R}} 3$ was somewhat enhanced (compare lanes 4 and 11).

DNase I protection of the bottom strand is consistent with that seen with the top strand, except that the protection of the $\mathrm{O}_{R} \mathrm{O}$ site is now apparent (Fig. 4B). Protection at $\mathrm{O}_{\mathrm{R}} 0$ is observed at repressor concentrations higher than those required for protection at $\mathrm{O}_{\mathrm{R}} 1$ and $\mathrm{O}_{\mathrm{R}} 2$. However, $\mathrm{O}_{\mathrm{R}} 0$ is protected at repressor concentrations that are about the same as those required for protection of $\mathrm{O}_{\mathrm{R}} 3$. As was seen with the top strand, the $\mathrm{O}_{\mathrm{R}} 1 \mathrm{~A}-\mathrm{T}$ mutation reduces protection at $\mathrm{O}_{\mathrm{R}} 1$, does not appear to significantly affect protection at $\mathrm{O}_{\mathrm{R}} 2$, and increases protection at $\mathrm{O}_{\mathrm{R}} 3$. There also appears to be a reduction in protection of the $\mathrm{O}_{R} 1 A-T$ mutant fragment at $\mathrm{O}_{R} 0$.

\section{DNase I protection of $O_{L}$}

Results of the DNase I protection assays of ${ }^{32} \mathrm{P}$-labelled $200 \mathrm{bp}$ DNA fragments, containing either the wild-type $\mathrm{O}_{\mathrm{L}}$ region or a variant with the $\mathrm{O}_{L} 1 \mathrm{~A} 4 \mathrm{~T}$ and $\mathrm{O}_{\mathrm{L}} 1 \mathrm{C} 6 \mathrm{~T}$ mutations, were consistent with the $\mathrm{H}-19 \mathrm{~B} \mathrm{O}_{\mathrm{L}}$ region having the three operator sites shown in Fig. 2A. As with our analysis of $O_{R}$, the DNase I protection results differed from the gel mobility shift assays, which were consistent with two binding sites in $\mathrm{O}_{\mathrm{L}}$.

Looking at DNAse I protection of the top strand (Fig. 5A), the protected regions correspond to two operator sites as suggested by the gel mobility shift experiments. Although an extended protected region immediately below the $\mathrm{O}_{\mathrm{L}} 1$ site can be observed, protection above $\mathrm{O}_{\mathrm{L}} 2$ expected for an $\mathrm{O}_{\llcorner} 3$ site cannot be observed. However, this is in the compressed part of the gel and evidence of protection may be obscured. As shown in Fig. 5A (lanes 7-12), the $O_{\llcorner} 1$ mutations eliminate repressor binding at $O_{L} 1$. However, in the absence of an effective $O_{\llcorner} 1$ site, the protection indicates that $\mathrm{O}_{L} 2$ binds repressor with the nearly the same affinity as when $O_{L} 1$ is intact, consistent with the results of the gel mobility shift assays.

Protection of the bottom strand (Fig. 5B), in addition to duplicating the identification of the $O_{L} 1$ and $O_{L} 2$, also identified the third repressor binding site in the $\mathrm{H}-19 \mathrm{~B} \mathrm{O}_{\mathrm{L}}$ region at the position of the $\mathrm{O}_{\mathrm{L}} 3$ sequence shown in 

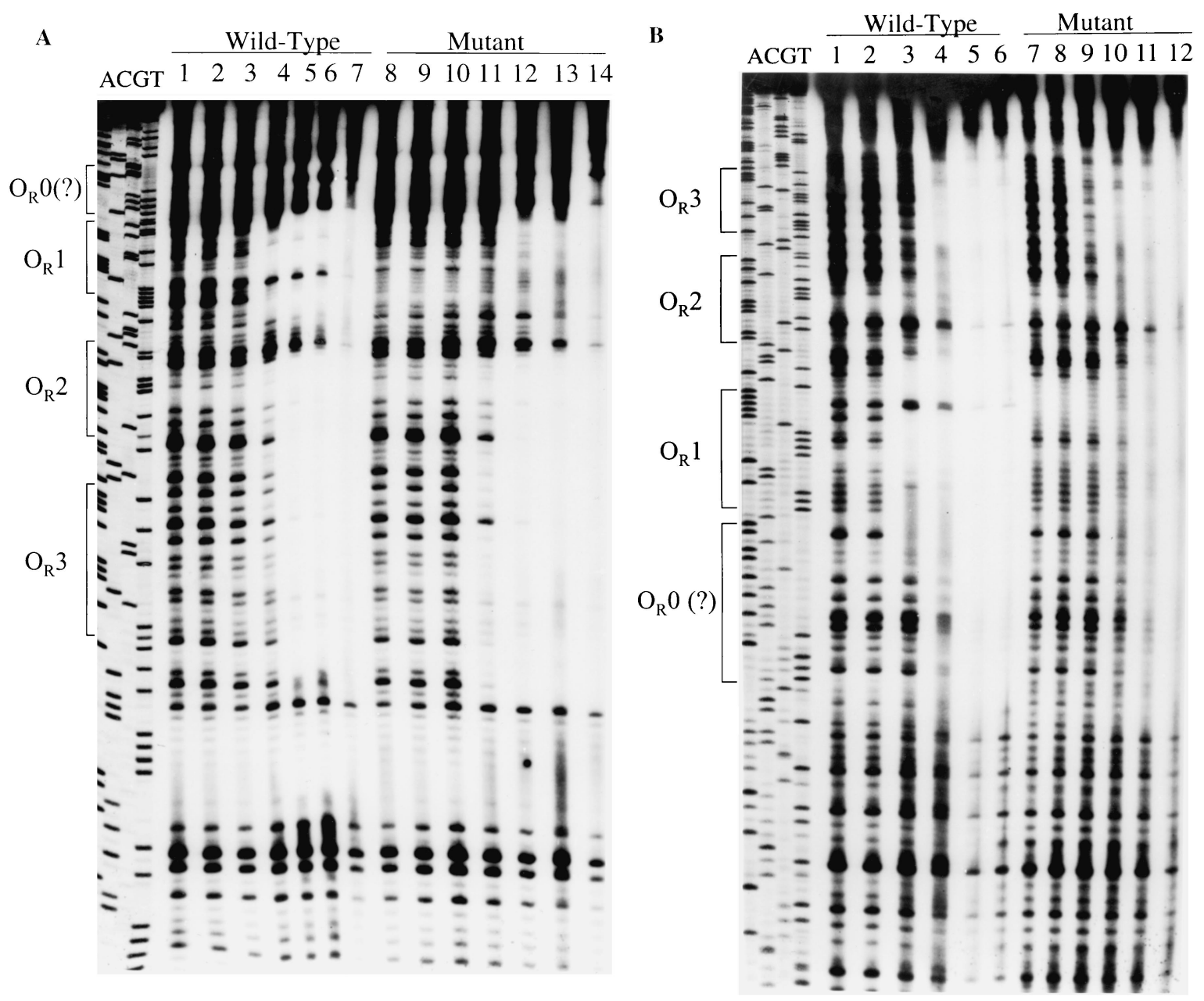

Fig. 4. DNase I protection experiment identifying repressor binding sites in the $\mathrm{H}-19 \mathrm{~B} \mathrm{O}_{\mathrm{R}}$ region. Details of procedure are found in Experimental procedures. DNA sequencing ladders are shown on the left. The $240 \mathrm{bp}{ }^{32} \mathrm{P}$-labelled DNA fragments contained either the wild type or the $\mathrm{O}_{\mathrm{R}} 1 \mathrm{~A}-\mathrm{T}$ mutant $\mathrm{O}_{R}$ regions. Protected sites are identified on the left.

A. Protection of top strand (corresponds to top strand of $\mathrm{O}_{\mathrm{R}}$ in Fig. 2A). Lanes 1 and 8 , cleavage without repressor, lanes $2-7$ and $9-14$, cleavage in the presence of twofold increases in repressor concentrations $(80,160,320,640,1280$ and $2560 \mathrm{nM})$. Lanes $1-7$, the DNA fragment contained the wild-type $\mathrm{O}_{\mathrm{R}}$ sequence; lanes 8-14, the DNA fragment contained the $\mathrm{O}_{\mathrm{R}} 1 \mathrm{~A} 4 \mathrm{~T}$ mutation.

B. Protection of bottom strand (corresponds to bottom strand of $O_{R}$ in Fig. 2A). Lanes 1 and 7, cleavage without repressor, lanes 2-6 and 8-12, cleavage in the presence of twofold increases in repressor concentrations $(160,320,640,1280$ and $2560 \mathrm{nM})$. Lanes 1-6, the DNA fragment contained the wild-type $O_{R}$ sequence and lanes 7-12 the DNA fragment contained the $O_{R} 1 A 4 T$ mutation.

Fig. 2A. The binding at $\mathrm{O}_{\mathrm{L}} 3$ appears to be different from that at $\mathrm{O}_{\mathrm{L}} 1$ and $\mathrm{O}_{\mathrm{L}} 2$; the binding is weaker and $\mathrm{O}_{\mathrm{L}} 3$ has two hypersensitive sites not seen at $O_{L} 1$ and $O_{L} 2$. Moreover, the 15 basepair spacing between these sites differs from the 7-8 basepair spacing between the other operator repeats excluding the 1 basepair spacing between $\mathrm{O}_{\mathrm{R}} 0$ and $\mathrm{O}_{\mathrm{R}} 1$.

\section{Binding of a truncated repressor protein}

The DNA binding domains of repressors of other lambdoid phages are located in the amino domain of the protein. To determine if the DNA binding domain of the $\mathrm{H}-19 \mathrm{~B}$ repressor is located in the amino portion of the protein, we assessed the effectiveness, in vivo and in vitro, of a truncated $\mathrm{H}-19 \mathrm{~B}$ repressor protein missing its 55 carboxyterminal amino acids. As discussed, when expressed from a plasmid, the truncated repressor is active in vivo (Table 1). To assess the action of the truncated protein, we used DNase I protection to examine repressor binding at the $\mathrm{H}-19 \mathrm{~B} \mathrm{O}_{\mathrm{R}}$ region. The truncated repressor binding appears very similar to binding of the full-sized repressor (data not shown).

\section{Identification of $\mathrm{P}_{R}$ and $\mathrm{P}_{R M}$ promoters}

The identification of a possible additional operator site, $\mathrm{O}_{\mathrm{R}} 0$ located between $\mathrm{O}_{\mathrm{R}} 1$ and cro (Fig. $2 \mathrm{~A}$ ), a site without a homologue in $\lambda$, raised the question of whether the positions of other regulatory elements located in the $\mathrm{H}-19 \mathrm{~B}$ 

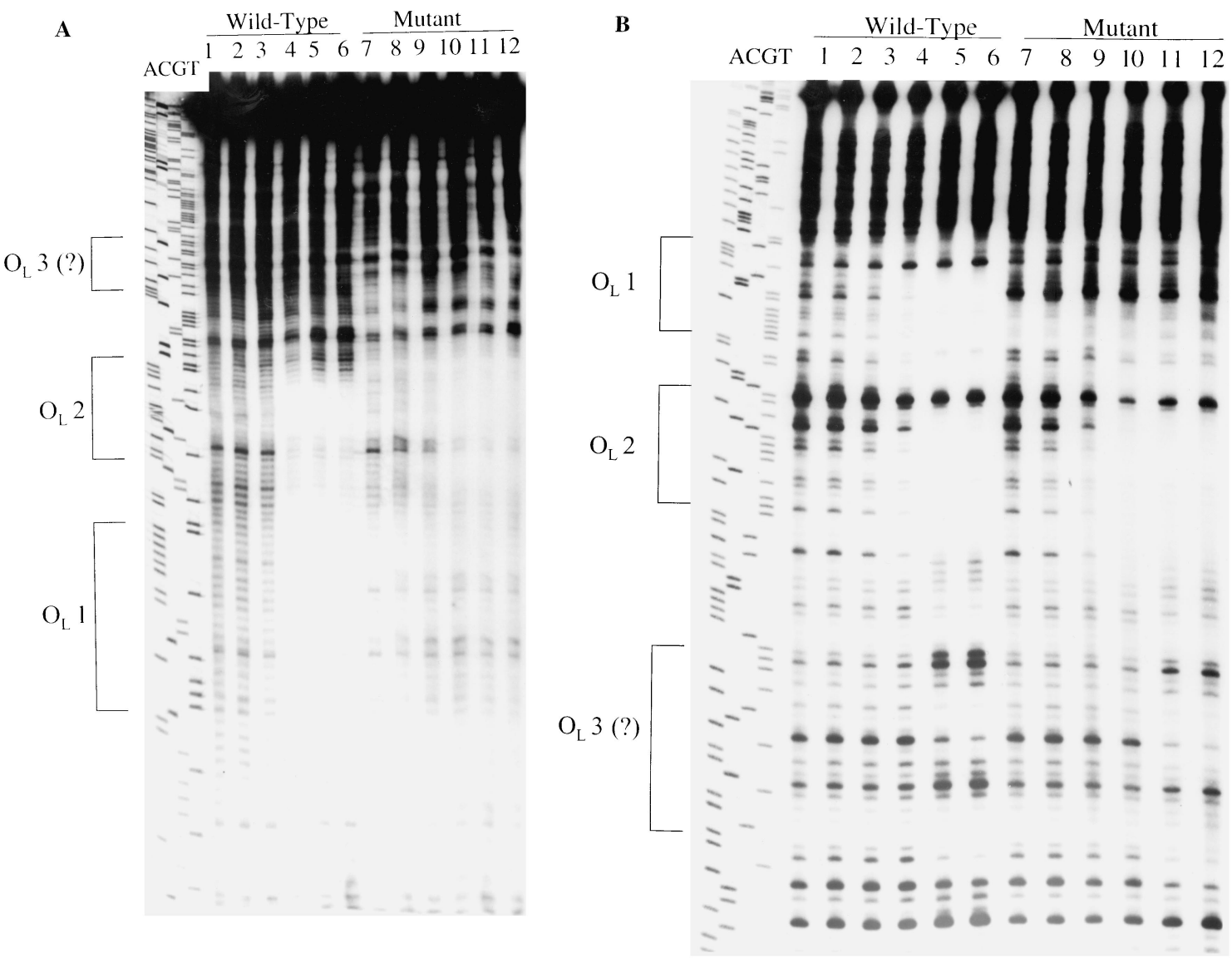

Fig. 5. DNase I protection with $\mathrm{H}-19 \mathrm{~B}$ repressor identifying binding sites in the $\mathrm{H}-19 \mathrm{~B} \mathrm{O}_{\mathrm{L}}$ region. Details of procedure are in Experimental procedures. DNA sequencing ladders are shown on the left. Lanes 1 and 7, cleavage without repressor, lanes 2-6 and 8-12, cleavage in the presence of twofold increases in repressor concentrations (160,320, 640, 1280 and $2560 \mathrm{nM})$. Lanes $1-6$, the DNA fragment contained the wildtype $O_{\llcorner}$sequence and lanes $7-12$ the DNA fragment contained the $O_{\llcorner} 1 A 4 T$ and $O_{\llcorner} 1 C 6 T$ mutations. Protected sites are identified on the left. A. Protection of top strand (corresponds to top strand of $\mathrm{O}_{\mathrm{L}}$ in Fig. $2 \mathrm{~A}$.

B. Protection of bottom strand (corresponds to bottom strand of $\mathrm{O}_{\mathrm{L}}$ in Fig. $2 \mathrm{~A}$ ).

$\mathrm{O}_{\mathrm{R}}$ region differ from the positions of their $\lambda$ homologues. Primer extension was used to locate the $P_{\mathrm{R}}$ and $P_{\mathrm{RM}}$ promoters (Fig. 6).

To identify the start site of the $P_{\mathrm{R}}$ transcript, RNA isolated after an infection of $\mathrm{K} 37$ with $\mathrm{H}-19 \mathrm{~B}$ was used as template for the primer extension. The primer extensions (as shown in Fig. 6A) consistently produced a wide band covering four nucleotides, suggesting the possibility of multiple transcription starts at $P_{\mathrm{R}}$ and, obviously, making it difficult to identify a specific start site for $P_{\mathrm{R}}$. However, based on the primer extensions, a sequence conforming to the consensus -10 sequence was identified at the $\mathrm{O}_{\mathrm{R}} 1$ sequence (Fig. 2A). This -10 sequence is located at precisely the same position relative to $\mathrm{O}_{\mathrm{R}} 1$ as is the $\lambda P_{\mathrm{R}}$ -10 sequence (Ptashne, 1992).

Primer extension was also used to identify the $P_{\mathrm{RM}}$ promoter. RNA isolated from K9949, the H-19B lysogen containing plmmH-19B, a plasmid with a $4.3 \mathrm{~kb}$ DNA fragment encoding the immunity region of $\mathrm{H}-19 \mathrm{~B}$ (see Experimental procedures for details). As shown in Fig. 2A, the start site of transcription, like that of $\lambda P_{\mathrm{RM}}$ (Ptashne, 1992 ) is located at the ATG translation initiation codon of the $\mathrm{Cl}$ gene. A sequence conforming to the consensus -10 sequence is located six nucleotides from this transcription start site (Fig. 2A); the same arrangement as observed for the $\lambda P_{\mathrm{RM}}$ promoter. However, the position of the putative $\mathrm{H}-19 \mathrm{~B} P_{\mathrm{RM}}$ differs from the position of the $\lambda$ $P_{\mathrm{RM}}$, in that the $\mathrm{H}-19 \mathrm{~B} P_{\mathrm{RM}}-10$ element is located six nucleotides outside $\mathrm{O}_{\mathrm{R}} 3$ (Fig. 2A), whereas the $\lambda P_{\mathrm{RM}}-10$ is located partially within the terminus of $\mathrm{O}_{\mathrm{R}} 3$.

\section{Induction of prophage}

To assess how the properties of the $\mathrm{H}-19 \mathrm{~B}$ operatorrepressor interactions influence induction of the $\mathrm{H}-19 \mathrm{~B}$ prophage, we compared spontaneous and mitomycin C-induced phage production from $\mathrm{H}-19 \mathrm{~B}$ and $\lambda$ lysogens constructed from strain K37. As shown in Table 2, there is not a significant difference in the spontaneous or induced yields of phage between these lysogens. 
A

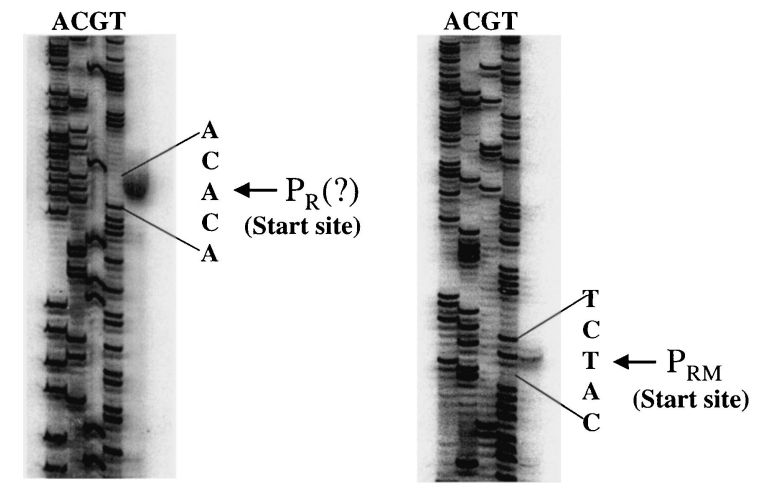

Fig. 6. Primer extensions identifying the start sites of transcription from the $P_{\mathrm{R}}$ and $P_{\mathrm{RM}}$ promoters. Details are outlined in Experimental procedures. DNA sequences were obtained using the same primers used to determine the transcription start sites. Arrows point to the start sites of transcription derived from the primer extension products. A. Extension with a primer directed toward the $P_{\mathrm{R}}$ promoter. A precise band indicating the start site of transcription was not attained. B. Extension with a primer directed toward the $P_{\mathrm{RM}}$ promoter.

\section{Discussion}

Largely through the studies from the Ptashne laboratory, the $\lambda$ operator-repressor duo has served as the basis for understanding the regulatory scheme of lambdoid phages, referred to as a 'genetic switch' (Ptashne, 1992). This regulatory mechanism determines the pathway of phage development, lytic or lysogenic. Attention has focused on the right operator, which controls transcription from both $P_{\mathrm{R}}$, the promoter directly or indirectly responsible for expression of nearly all genes encoding functions required for lytic growth, and $P_{\mathrm{RM}}$, the promoter that maintains repressor expression in the lysogen (Johnson et al., 1981). Repressor binding at the operator sites also regulates its own expression by activating transcription from $P_{\mathrm{RM}}$ (Gussin et al., 1983). We have constructed an H-19B virulent mutant that differs from the classical $\lambda$ virulent mutant in having one mutation each in $\mathrm{O}_{\mathrm{L}}$ and $\mathrm{O}_{\mathrm{R}}$, rather than the two mutations in $\mathrm{O}_{R}$ and one mutation in $\mathrm{O}_{L}$ (Hopkins and Ptashne, 1971). Therefore, there appears to be a difference in the required mutations for virulence in $\lambda$ and $\mathrm{H}-19 \mathrm{~B}$. A later study revealed that $\lambda$ virulent mutants could be obtained that had either two mutations in $\mathrm{O}_{R}$ and one in $\mathrm{O}_{\mathrm{L}} 1$ or one mutation in $\mathrm{O}_{\mathrm{R}}$ and two in $\mathrm{O}_{\mathrm{L}} 2$ (Flashman, 1978), indicating that virulence in $\lambda$ requires three mutations, two in one operator and one in the other, but the two can be in either $\mathrm{O}_{\mathrm{R}}$ or $\mathrm{O}_{\mathrm{L}}$. Studies with other lambdoid phages have defined the mutational requirements for virulence in $\mathrm{O}_{\mathrm{R}}$. P22 and HK022, like the classical $\lambda$ virulent mutant, require two mutations in the $O_{R}$ region (Poteete et al., 1980; Carlson and Little, 1993a), 434 and 21 require only one mutation in $\mathrm{O}_{\mathrm{R}}$ (Poteete et al., 1980; Wharton et al., 1984).

Isolation of an $\mathrm{H}-19 \mathrm{~B}$ virulent mutant coupled with repressor binding studies allowed us to definitively identify the operator regions and repressor $(\mathrm{cl})$ gene of this phage. We have named the imperfect inverted repeat in the $\mathrm{O}_{R}$ region second from the cro gene $\mathrm{O}_{\mathrm{R}} 1$ (Fig. 2A). Although the repeat closest to the cro gene is typically given that name, the inverted repeat we have named $\mathrm{O}_{R} 1$ has the functional characteristics of the $\mathrm{O}_{R} 1$ inverted repeats of other lambdoid phages (Bushman, 1993). In addition to being the site of a point mutation sufficient to eliminate effective repression at $O_{R}$, the $O_{R} 1$ inverted repeat binds repressor more effectively than does the $\mathrm{O}_{R} 0$ inverted repeat (Figs 4 and 5). Moreover, our primer extension studies locate the $\mathrm{H}-19 \mathrm{~B} P_{\mathrm{R}}$ promoter in what we identify as $\mathrm{O}_{\mathrm{R}} 1$ precisely as the $\lambda P_{\mathrm{R}}-10$ is positioned relative to the $\lambda \mathrm{O}_{\mathrm{R}} 1$ sequence. If this analysis is correct, the functional role, if any, for $\mathrm{O}_{\mathrm{R}} \mathrm{O}$ is unclear.

The gel mobility shift experiments are consistent with the presence of two repressor binding sites in the $\mathrm{O}_{L}$ region and three in the $\mathrm{O}_{R}$ region. The DNase I protection studies identify the specific repressor binding sites within the operator regions: three in $\mathrm{O}_{\mathrm{L}}$ and four in $\mathrm{O}_{\mathrm{R}}$. The fourth site, $\mathrm{O}_{\mathrm{R}} 0$, located between $\mathrm{O}_{\mathrm{R}} 1$ and cro, is observed in the DNase I protection of the bottom strand. The fact that the protection observed in the bottom strand covers the entire $\mathrm{O}_{\mathrm{R}} 0$ inverted repeat suggests that $\mathrm{O}_{\mathrm{R}} 0$ is a bona fide repressor binding site. However, we cannot rule out the possibility that the repressor binding at $\mathrm{O}_{R} 0$ does not result from binding to DNA, but results from a protein-protein interaction with repressor bound at $\mathrm{O}_{\mathrm{R}} 1$; this type of binding has been reported for the HK022 repressor (Carlson and Little, 1993a). A fourth operator site has been identified to the right of the $c$ l gene of phage HK022 (Carlson and Little, 1993b). This operator site, $\mathrm{O}_{\mathrm{FR}}$, is also located to the cro side of $\mathrm{O}_{R} 1$ but, instead of being directly adjacent to $\mathrm{O}_{\mathrm{R}} 1, \mathrm{O}_{\mathrm{FR}}$ is separated from $\mathrm{O}_{\mathrm{R}} 1$ by the cro gene. $\mathrm{O}_{\mathrm{FR}}$ is biologically important because it is a necessary component along with a mutation in either $\mathrm{O}_{\mathrm{R}} 1$ or $\mathrm{O}_{\mathrm{R}} 2$ of some HK022 virulent mutants. However, in any comparison with $\mathrm{HK} 022$, it must be kept in mind that because of the peculiarity of antitermination in the early operons of HK022 (Weisberg et al., 1999), virulence in that

Table 2. Comparison of phage production by $\mathrm{H}-19 \mathrm{~B}$ and $\lambda$ lysogens.

\begin{tabular}{lll}
\hline \multirow{2}{*}{ Method of Induction } & \multicolumn{2}{c}{${\text { Phage } \mathrm{ml}^{-1 \mathrm{a}} \text { produced by lysogens }}^{\mathrm{b}}$} \\
\cline { 2 - 3 } & $\mathrm{K} 9951(\lambda)$ & $\mathrm{K} 9774(\mathrm{H}-19 \mathrm{~B})$ \\
\hline Spontaneous & $7.6( \pm 0.5) \times 10^{5}$ & $1.2( \pm 0.1) \times 10^{5}$ \\
Mitomycin C & $5.2( \pm 1.3) \times 10^{9}$ & $6.2( \pm 1.8) \times 10^{9}$ \\
\hline
\end{tabular}

a. See Experimental procedures for details. Numbers are average of three individual experiments. Standard deviations are shown in parenthesis.

b. Strains are lysogens of K37 containing the prophage identified in the parenthesis. 
phage only requires elimination of effective repressor binding at $\mathrm{O}_{\mathrm{R}}$ (Carlson and Little, 1993a). The added requirement for a mutation in $\mathrm{O}_{\mathrm{FR}}$ for virulence is postulated to serve as a mechanism to reduce the chances of HK022 mutating to virulence.

The DNase I protection studies suggest that repressor binding at $\mathrm{H}-19 \mathrm{~B}$ operators may be somewhat unusual. We briefly consider these results, bearing in mind that the results could be influenced by the tag located on the carboxy terminus of the repressor used in our studies. As discussed above, studies on $\lambda$, as well as other lambdoid phages, have focused on repressor binding at $\mathrm{O}_{\mathrm{R}}$ regions because of the important regulatory activities occurring within those regions. In the $O_{R}$ regions of these phages (e.g. $\lambda, 434$, and $\mathrm{HK} 022$ ), cooperative binding at $\mathrm{O}_{\mathrm{R}} 1$ and $\mathrm{O}_{\mathrm{R}} 2$ results in tight binding of repressor at those sites (Ptashne, 1992; Carlson and Little, 1993a; Koudelka and Lam, 1993), with substantially weaker binding at $\mathrm{O}_{\mathrm{R}} 3$. Our DNase I protection studies suggest the possibility of a different mode of repressor binding in the $\mathrm{H}-19 \mathrm{~B} \mathrm{O}_{\mathrm{R}}$ region. Although repressor binding appears to occur first at the $\mathrm{O}_{\mathrm{R}} 1$ site, binding at the $\mathrm{O}_{\mathrm{R}} 2$ and $\mathrm{O}_{\mathrm{R}} 3$ sites occurs at only a slightly higher repressor concentration. Moreover, the strength of binding at $\mathrm{O}_{\mathrm{R}} 2$ appears to be independent of repressor binding at $\mathrm{O}_{\mathrm{R}} 1$. For $\lambda, 434$ and HK022, the binding at $\mathrm{O}_{\mathrm{R}} 1$ and $\mathrm{O}_{\mathrm{R}} 2$ stimulates $c \mathrm{l}$ transcription from $P_{\mathrm{RM}}$, whereas binding at all three operators turns off transcription from $P_{\mathrm{RM}}$ (Hochschild et al., 1983;Cam et al., 1991; Bushman, 1993; Carlson and Little, 1993a). A different picture was observed with $\phi 80$ (Ogawa et al., 1988), one more closely resembling that which we observe with $\mathrm{H}-19 \mathrm{~B}$. Tightest repressor binding in each of the $\phi 80$ operator regions is to the second repeat: i.e. $\mathrm{O}_{\mathrm{R}} 2$ and $\mathrm{O}_{\mathrm{L}} 2$. Although this binding pattern differs from that of the $\lambda$ paradigm, the following argument was raised suggesting that regulation of transcription from $P_{\mathrm{RM}}$ in $\phi 80$ might not differ from that in $\lambda$. Because repressor binding to $\mathrm{O}_{\mathrm{R}} 2$ occurs before binding to $\mathrm{O}_{R} 3$, repressor binding at $\mathrm{O}_{\mathrm{R}} 2$ could activate transcription from $P_{\mathrm{RM}}$ even if binding at $\mathrm{O}_{\mathrm{R}} 3$ blocks transcription from $P_{\mathrm{RM}}$. A similar role for binding at $\mathrm{O}_{\mathrm{R}} 2$ could explain how transcription from $P_{\mathrm{RM}}$ could be regulated by repressor binding in $\mathrm{H}-19 \mathrm{~B}$.

In some lambdoid phages competition between $P_{\mathrm{R}}$ and $P_{\mathrm{RM}}$ for binding of RNAP could influence expression of transcription from $P_{\mathrm{RM}}$. The distance between the two promoters would appear to be a significant factor in this competition. Promoter competition is observed between $P_{\mathrm{R}}$ and $P_{\mathrm{RM}}$ in lambdoid phages 434, in which the transcription start sites are separated by $66 \mathrm{bp}$, and P22, in which the transcription start sites are separated by $52 \mathrm{bp}$ (Bushman, 1993; Strainic et al., 2000; Xu and Koudelka, 2000). Competition between $P_{\mathrm{R}}$ and $P_{\mathrm{RM}}$ for RNAP binding is not observed in $\lambda$, in which the transcription start sites are separated by $83 \mathrm{bp}$. However, binding of RNAP at $P_{\mathrm{R}}$ does modulate activity of $P_{\mathrm{RM}}$ (Hershberger and deHaseth, 1991; Fong et al., 1993). It is unlikely that competition for RNAP binding plays a role in regulating $\mathrm{H}-19 \mathrm{~B}$ repressor expression because the start sites of the $\mathrm{H}-19 \mathrm{~B} P_{\mathrm{RM}}$ and $P_{\mathrm{R}}$ promoters are separated by $\sim 90 \mathrm{bp}$ (Fig. $2 \mathrm{~A}$ ), substantially greater than the separations between the $P_{\mathrm{RM}}$ and $P_{\mathrm{R}}$ promoters of other characterized lambdoid phages. However, we can not rule out the possibility that binding of RNAP to $P_{\mathrm{R}}$ modulates RNAP binding at $P_{\mathrm{RM}}$.

The repressor used in these in vitro studies, although carrying a His-tag on its carboxy terminus, is active in vivo, conferring immunity from infection by $\mathrm{H}-19 \mathrm{~B}$. The in vivo studies also show that this immunity results from physiologically correct repressor action; although the bacterium expressing the His-tagged repressor fails to support infection with $\mathrm{H}-19 \mathrm{~B}$, it does support infection with $\mathrm{H}-19 \mathrm{Bvir}$ and lambdoid phages with immunities differing from that of $\mathrm{H}-19 \mathrm{~B}$. Therefore, although suggesting that the tag does not have a significant effect on repressor interactions, this conclusion must be tempered by additional findings with $\mathrm{H}-19 \mathrm{~B}$ and $\lambda$ repressors. First is our finding that a His-tagged repressor truncated by 55 amino acid residues at the carboxy terminus is also active in vivo. Thus, either the terminal 55 amino acids, missing in the truncated repressor protein, are not functionally important or our immunity assay does not provide a complete assessment of repressor interactions. Second is the finding that, when expressed from a plasmid, a mutant $\lambda$ repressor with a defect in cooperative binding confers immunity to $\lambda$ infection (Astromoff and Ptashne, 1995). Thus, some of the novel aspects of our findings could reflect the fact that the purified His-tagged repressor we used in these studies may not behave like wild-type repressor.

Any differences in the nature of the mechanisms controlling maintenance of repressor expression observed between $\mathrm{H}-19 \mathrm{~B}$ and the $\lambda$ paradigm is not reflected in the maintenance of repression as measured by spontaneous or mitomycin C-stimulated prophage induction.

\section{Experimental procedures}

\section{Bacteria, bacteriophages and plasmids}

Plasmids. pREP4 (Qiagen) is a derivative of pACYC that overexpresses lac repressor. pQE-60 (Qiagen) was used as the expression vector for the His-tagged $\mathrm{H}-19 \mathrm{~B} \mathrm{Cl}$ proteins. This plasmid has a T5 promoter regulated by two lac operators followed by a multicloning region with a sequence encoding a six histidine tag at its $3^{\prime}$ end. plac- $\mathrm{N}(\mathrm{H}-19 \mathrm{~B})$, a derivative of pGB2, was used to supply $\mathrm{H}-19 \mathrm{~B} N$ (Neely and Friedman, 1998b). pQE-H-19B $\mathrm{cl}$ and $\mathrm{pQE}-\mathrm{H}-19 \mathrm{~B} c$ ltrc are derivatives of $\mathrm{pQE}-60$ with the cloned fragments encoding the full-sized $\mathrm{H}-19 \mathrm{~B} \mathrm{Cl}$ protein and a truncated $\mathrm{H}-19 \mathrm{~B} \mathrm{Cl}$ protein missing the carboxy terminal 55 amino acids respectively (see 


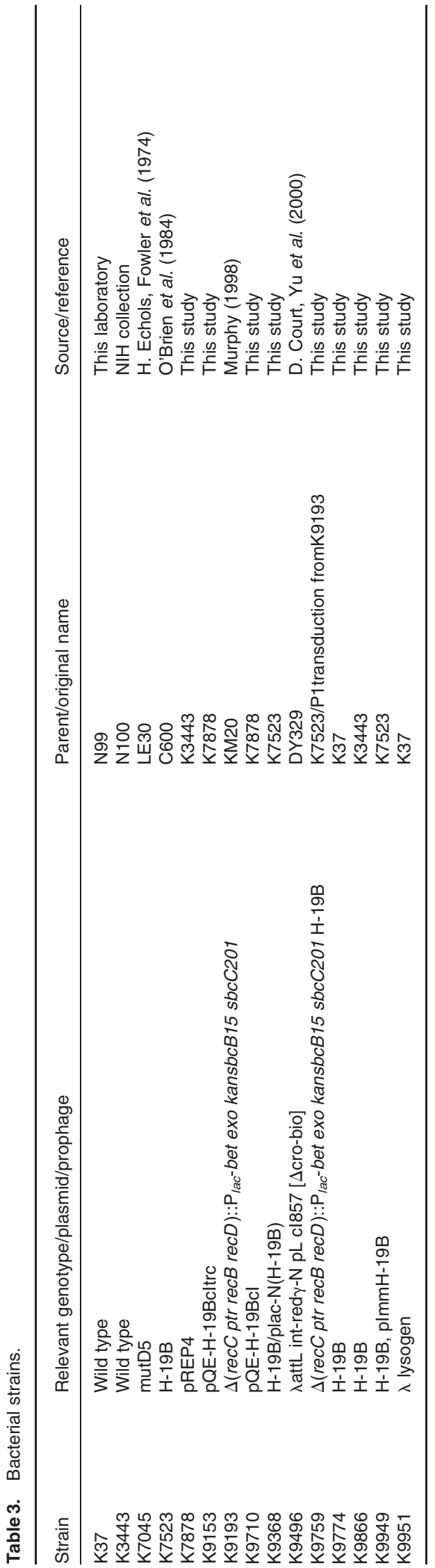

below for details on their construction). plmmH-19B is a derivative of pBR325 with a $4.3 \mathrm{~kb}$ fragment that includes the immunity region of H-19B (Neely and Friedman, 1998a).

Phage. $\mathrm{H}-19 \mathrm{~B}$ phage was obtained by mitomycin $\mathrm{C}$ induction of the $\mathrm{H}-19 \mathrm{~B}$ lysogen $\mathrm{K} 7523$.

Bacteria. The relevant genotypes and sources of bacterial strains used in this study are listed in Table 3.

\section{Media}

LB (Luria-Bertani), TB (Tryptone) broth and plates and top agar have previously been described (Miller and Friedman, 1980).

\section{Construction of $\mathrm{H}-19 \mathrm{~B} \mathrm{C}$ / expression plasmids}

Polymerase chain reaction (PCR) was used to synthesize DNA fragments encoding either the full-sized or a truncated form of the $\mathrm{H}-19 \mathrm{~B}$ repressor. The primers in the PCR reactions contained $\mathrm{Bam} \mathrm{H} 1$ or $\mathrm{Nco1}$ sites. The template was DNA isolated from the $\mathrm{H}-19 \mathrm{~B}$ lysogen K7523. Standard cloning procedures were used to place the PCR products in the pQE-60 expression vector positioned so that the $c \mid$ gene is transcribed from the T5 promoter. Primers used in constructing the fragment encoding the full-sized $\mathrm{H}-19 \mathrm{~B}$ repressor were (5'-CCCGCGGATCCCGAACTTTTCAGCCA CTCCCTTGCCT-3') and (5'-CATGCCATGGAAAACAAAGA TATTCG- $3^{\prime}$ ). Primers used in constructing the fragment encoding the truncated form of the $\mathrm{H}-19 \mathrm{~B}$ repressor were (5'-CGGGATCCTATGCCAAGAACTTTGATCATG-3') and (5'-CATGCCATGGAAAACAAAGATATTCG-3').

\section{Phage techniques}

Efficiency of plating and determination of phage titres have been described elsewhere (Friedman et al., 1984; Mozola et al., 1979).

\section{Mutagenesis}

Construction of $\mathrm{H}-19 B$ derivatives with an $\mathrm{O}_{R}$ mutation. A recombination system based on the $\lambda$ Red functions (Murphy, 1998) was used to enhance homologous recombination between a mutagenized collection of DNA fragments, created using PCR-generated random mutagenesis (Zhou et al., 1991) and an $\mathrm{H}-19 \mathrm{~B}$ prophage. K9759, the $\mathrm{H}-19 \mathrm{~B}$ lysogen that can be induced to express $\lambda$ recombination functions, was grown in LB made $2 \mu \mathrm{M}$ in IPTG (isopropylthiogalactoside) prior to being made competent for electroporation. The template used in the $\mathrm{PCR}$ reactions was a DNA fragment containing the wild-type $\mathrm{H}-19 \mathrm{~B} \mathrm{O}_{\mathrm{R}}$ region. The linear $1 \mathrm{~kb}$ collection of mutagenized PCR products were electroporated into the competent bacteria. Transformed bacteria were grown in LB for $3 \mathrm{~h}$ at $37^{\circ} \mathrm{C}$ and then for another $2 \mathrm{~h}$ in the presence of $2 \mu \mathrm{g} \mathrm{ml}^{-1}$ mitomycin $\mathrm{C}$ to induce the $\mathrm{H}-19 \mathrm{~B}$ prophage. The resulting lysate was used to select a partially virulent phage with a mutation(s) in $\mathrm{O}_{\mathrm{R}}$. The mutant phage, $\mathrm{H}-19 \mathrm{BvirR}-1$, was identified as a variant that 
formed a plaque on $\mathrm{K} 9368$, an $\mathrm{H}-19 \mathrm{~B}$ lysogen containing the $\mathrm{N}$ expressing plac- $\mathrm{N}(\mathrm{H}-19 \mathrm{~B})$ plasmid.

Construction of a fully virulent $H-19 B$. A lysate of the $\mathrm{H}-19 B$ virR-1 mutant propagated in the mutator strain K7045 was used to generate fully virulent $\mathrm{H}-19 \mathrm{~B}$ mutants, isolated by their ability to form plaques on a lawn of the $\mathrm{H}-19 \mathrm{~B}$ lysogen K7523.

Construction of fully virulent mutants with a single mutation in $O_{L}$. DNA fragments with only one of the two mutations in the $\mathrm{O}_{\mathrm{L}} 1$ were generated by directed mutagenesis using splicing by overlap extension (Horton et al., 1990) to synthesize $\mathrm{O}_{L}$ DNA fragments with either the $\mathrm{O}_{L} 1 A 4 T$ or $\mathrm{O}_{\mathrm{L}} 1 \mathrm{C6T}$ mutations. DNA isolated from $\mathrm{K} 7523$, an $\mathrm{H}-19 \mathrm{~B}$ lysogen, served as the template. Primers used for generating the $\mathrm{O}_{\mathrm{L}} 1 \mathrm{~A} 4 \mathrm{~T}$ mutation were: (5'-ATAAAAACAACCGTTAAC GT-3'), (5'-TTTATCGGAATAATAAATTAATG-3'), (5'-CGTAA AGAGCTACATTTGGA-3') and (5'-CATTAATTTATTATTCC GATA AA- $\left.3^{\prime}\right)$.

Primers used for generating the $\mathrm{O}_{\mathrm{L}} 1 \mathrm{C} 6 \mathrm{~T}$ mutation were: (5'-ATAAAAACAACCGTTAACGT-3'), (5'-TTTATCGGAAT GAAAAATTAATGGC-3'), (5'-CGTAAAGAGCTACATTTG GA-3') and (5'-GCCATTAATTTTTCATTCCGATAAA-3'). The PCR-generated DNA fragments with the $O_{L}$ mutations were crossed onto the genomes of the partially virulent phage, $\mathrm{H}-19 \mathrm{Bvir}-1$, using a variation of the method developed by $\mathrm{Yu}$ et al. (2000). Strain K9496 infected with the H-19Bvir-1 mutant was incubated on ice for $20 \mathrm{~min}$ to allow adsorption. The infected bacteria were then incubated at $37^{\circ} \mathrm{C}$ for $5 \mathrm{~min}$, shifted to $42^{\circ} \mathrm{C}$ for $10 \mathrm{~min}$ (to induce expression of the $\lambda$ recombination functions), put on ice and then made competent for electroporation. The constructed fragments with $\mathrm{O}_{\mathrm{L}}$ mutations were electroporated into the competent bacteria. The bacteria were diluted into $\mathrm{LB}$ and grown at $37^{\circ} \mathrm{C}$ for approximately $3 \mathrm{~h}$. Fully virulent $\mathrm{H}-19 \mathrm{~B}$ mutants were isolated from the supernatants as phages that form plaques on strain K7523, an H-19B lysogen.

\section{Isolation and purification of the $\mathrm{H}-19 \mathrm{~B} \mathrm{Cl}$ repressor proteins}

One litre cultures of bacteria, K9153 (truncated Cl) or K9710 (full-sized $\mathrm{Cl}$ ), were grown in LB with vigorous shaking to an $\mathrm{OD}_{600}$ of $\sim 0.7$. IPTG was added to a final concentration of 1-2 $\mathrm{mM}$ to turn on expression of the T5 RNA polymerase, resulting in transcription of the cloned $c$ l gene and production of $\mathrm{Cl}$ protein. The incubation was continued for another $2-3 \mathrm{~h}$. Harvested bacteria were resuspended in wash buffer $(50 \mathrm{mM}$ $\mathrm{NaH}_{2} \mathrm{PO}_{4}, \mathrm{pH} 8.0 ; 300 \mathrm{mM} \mathrm{NaCl}, 10 \mathrm{mM}$ imidazole) and stored at $-70^{\circ} \mathrm{C}$ until use. Bacterial suspensions were lysed using a French Pressure cell and the His-tagged derivatives of the $\mathrm{H}-19 \mathrm{~B} \mathrm{Cl}$ protein were isolated using a $\mathrm{Ni}^{++}$column as per the manufacturer's instructions (Qiagen).

\section{Preparation of ${ }^{32} P$-labelled DNA fragments}

Fragments ( $\sim 200$ bp in length) were generated by PCR using $\mathrm{H}-19 \mathrm{~B}$ DNA as the template. The $5^{\prime}$ end of one of the primers was labelled using $\left[\gamma^{-32} \mathrm{P}\right]-$ ATP and T4 polynucleotide kinase
(Life Technologies). The labelling reaction mixture, containing $10 \mathrm{pmol}$ of primer, forward reaction buffer $[70 \mathrm{mM}$ Tris- $\mathrm{HCl}$ (pH7.6), $10 \mathrm{mM} \mathrm{MgCl}, 100 \mathrm{mM} \mathrm{KCl}$ and $1 \mathrm{mM}$ 2-mercaptoethanol], 20 units of T4 polynucleotide kinase, $50 \mu \mathrm{Ci}$ of $\left[\gamma^{-}{ }^{32} \mathrm{P}\right]-A T P$ in a total volume of $50 \mu \mathrm{l}$, was incubated at $37^{\circ} \mathrm{C}$ for $30 \mathrm{~min}$ and then at $70^{\circ} \mathrm{C}$ for $10 \mathrm{~min}$. The total labellingreaction mix was added to a PCR reaction mix containing the second primer, and the combined mixture used directly in a $\mathrm{PCR}$ reaction to generate the end-labelled probe. The labelled probes, used in the gel mobility shift and DNase I protection assays, were purified using a PCR purification kit according to the manufacturer's directions (Qiagen). The primers used for generating the right operator $\left(\mathrm{O}_{\mathrm{R}}\right)$ probes were: $\left(5^{\prime}\right.$-CCCA AGCTTACGCCAGATTCGA-3') and (5'-CGGGATCCTCAC-CGGGATCCTCACTAGAAGCCTC). The primers used for generating the left operator $\left(\mathrm{O}_{\mathrm{L}}\right)$ probes were: (5'-CCCAA GCTTGGGTGAGTAGTGCGT-3') and (5'-CGGGATCCAGA TCTCCСTCAAATCTCTTTAT-3).

\section{Gel mobility shifts}

The procedure was performed essentially as previously described (Crawford et al., 1998) with only slight modifications. The binding reaction was carried out in a total volume of $20 \mu \mathrm{l}$ of binding buffer containing $10 \mu \mathrm{g} \mathrm{ml}^{-1}$ salmon sperm DNA. The concentrations of $\mathrm{H}-19 \mathrm{~B}$ repressor protein in the binding reaction mixtures varied by twofold increments that ranged from $60 \mathrm{nM}$ to $1800 \mathrm{nM}$. The concentration of $\lambda$ repressor and BSA in the control reactions was $\sim 1500 \mathrm{nM}$ 20000 c.p.m. of ${ }^{32} \mathrm{P}$-labelled DNA fragments was used in each reaction and the binding reaction was incubated at $37^{\circ} \mathrm{C}$ for $30 \mathrm{~min}$. Samples were electrophoresed in a $6 \%$ nondenaturing polyacrylamide gel. The resulting gel was exposed to film with intensifying screen overnight.

\section{DNase I protection}

DNase I protection assay used the same binding buffer as DNA gel mobility shift assay. The binding reactions were performed as previously described (Crawford et al., 1998). The reaction mixture containing $14 \mu \mathrm{l}$ of $5 \times$ binding buffer (10 mM Tris-HCl, pH7.4, 1 mM EDTA, 10\% glycerol, $50 \mu \mathrm{g} \mathrm{ml}^{-1}$ BSA, $\left.500 \mathrm{mM} \mathrm{KCl}\right), 7 \mu \mathrm{l}$ of salmon sperm DNA $\left(0.1 \mathrm{mg} \mathrm{ml}^{-1}\right), 1 \mu \mathrm{l}$ of probe (70000 c.p.m., $\sim 15 \mathrm{ng}$ of ${ }^{32} \mathrm{P}$-labelled fragment) and the desired amount of $\mathrm{H}-19 \mathrm{~B}$ repressor was made to a final volume of $70 \mu \mathrm{l}$ with $\mathrm{H}_{2} \mathrm{O}$. After a 30 minute incubation at $37^{\circ} \mathrm{C}, 17 \mu \mathrm{l}$ of $\mathrm{H}_{2} \mathrm{O}, 11 \mu \mathrm{l}$ of $50 \mathrm{mM}$ $\mathrm{MgCl}_{2}, 2 \mu \mathrm{l}$ of $50 \mathrm{mM} \mathrm{CaCl}$, and $1 \mu \mathrm{l}$ of DNase I $(0.01$ unit $\mu^{-1}$ I) were added to the mixture, which was gently mixed and incubated for $2 \mathrm{~min}$ at room temperature. DNase I digestion was stopped by adding $100 \mu$ l of stop solution (200 mM NaCl, $2 \mathrm{mM}$ EDTA, 1\% SDS) to the mixture, which was then extracted twice with equal volumes of phenol and chloroform: isoamyl alcohol $(24: 1)$ to remove the protein. The

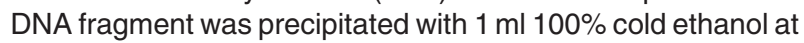
$-70^{\circ} \mathrm{C}$ for at least $1 \mathrm{~h}$, collected by centrifugation, washed with $70 \%$ ethanol once and resuspended in $5-10 \mu$ of formamide stop dye. The precipitated DNA fragment was electrophoresed on a denaturing polyacrylamide-urea $(6.88 \mathrm{M})$ gel for $\sim 3 \mathrm{~h}$. The gel was dried for $1 \mathrm{~h}$ at $80^{\circ} \mathrm{C}$ and exposed to film at $-70^{\circ} \mathrm{C}$ with intensifying screens overnight. 
${ }^{33} \mathrm{P}$-labelled sequencing ladders covering $\mathrm{H}-19 \mathrm{~B}$ operator regions were run in parallel.

\section{Primer extension}

The procedure was essentially that described by $\mathrm{Yu}$ and DiRita (1999). The source of RNA for the primer extension to determine the start site of transcription from $P_{\mathrm{RM}}$ was K9949, an $\mathrm{H}-19 \mathrm{~B}$ lysogen with plmmH-19B. Some modification was required in isolating the RNA for the primer extension to determine the start site of transcription from $P_{\mathrm{R}}$. In this case, bacteria infected with $\mathrm{H}-19 \mathrm{~B}$ were used as the source of the RNA. An overnight culture of E. coli strain K37 grown in LB was diluted 1:100 into fresh LB medium and grown to log phase. The cells were collected by centrifugation, resuspended at one tenth volume in $0.01 \mathrm{M} \mathrm{Mg}^{++}$, infected with $\mathrm{H}-19 \mathrm{~B}$ at a m.o.i. of 10 , and incubated on ice for $20 \mathrm{~min}$ to allow adsorption. The volume of the infected bacteria mixture was brought to $50 \mathrm{ml}$ in LB, and the diluted bacteria were incubated with shaking at $37^{\circ} \mathrm{C}$ for $30 \mathrm{~min}$. The infected cells were collected and treated according to the method outlined by Yu and DiRita (1999).

The sequence used as the primer (5'-TCTGGTCAAGATA GCCAACTGAAGTTTTCGCTAATGCGGC-3') to determine the start of transcription of $P_{\mathrm{R}}$ was that of the sense strand beginning $60 \mathrm{bp}$ downstream of the $5^{\prime}$ end of the cro gene. The sequence used as the primer (5'-GCTTATCGGCAAAGCTTG CATTAGTGTTACCCGCGATTTT-3') to determine the start site of transcription from $P_{\mathrm{RM}}$ was that of the sense strand beginning $57 \mathrm{bp}$ downstream of the $5^{\prime}$ end of the $\mathrm{cl}$ gene.

\section{DNA sequencing}

DNA sequences were obtained using the Thermosequenase kit (USB).

\section{Phage production by lysogens}

Overnight cultures of lysogens grown in LB broth were diluted $1: 100$ into LB broth and grown to an $O_{600}$ of $\sim 0.45$. One aliquot was immediately treated with chloroform, bacteria were sedimented by centrifugation and the supernatant assayed for phage titre. The second aliquot was made $4 \mu \mathrm{ml}^{-1}$ in mitomycin $\mathrm{C}$ per $\mathrm{ml}$ and incubated with shaking for an additional $2 \mathrm{~h}$. The culture was treated with chloroform, sedimented by centrifugation and the supernatant assayed for phage titre.

\section{Acknowledgements}

The authors thank Victor DiRita, Jeff Withey and Dennis Thiele for critically reading the manuscript. Dennis Thiele, John Little, Melody Neely, Gary Glick, Robert Martin, and all of the members of our laboratory are thanked for helpful discussion. The work was supported grant Al43023 from the National Institutes of Health.

\section{References}

Acheson, W.K., Donohue-Rolfe, A., and Keusch, G.T. (1991)
The family of Shiga and Shiga-like toxins. In: Sourcebook of Bacterial Protein Toxins. Alouf, J.E., and Freer, J.H. (eds). London: Academic Press, pp. 415-433.

Astromoff, A., and Ptashne, M. (1995) A variant of lambda repressor with an altered pattern of cooperative binding to DNA sites. Proc Natl Acad Sci USA 92: 8110-8114.

Bushman, F.D. (1993) The bacteriophage 434 right operator roles of $\mathrm{O}_{\mathrm{R}} 1, \mathrm{O}_{\mathrm{R}} 2$ and $\mathrm{O}_{\mathrm{R}} 3$. $\mathrm{J} \mathrm{Mol} \mathrm{Biol} \mathrm{230:} \mathrm{28-40.}$

Cam, K.M., Oberto, J., and Weisberg, R.A. (1991) The early promoters of bacteriophage HK022: contrasts and similarities to other lambdoid phages. J Bacteriol 173: 734-740.

Campbell, A. (1988) Phage evolution and speciation. In the Bacteriophages 1. Calendar, R., (ed.) New York: Plenum Press, pp. 1-14.

Carlson, N.G., and Little, J.W. (1993a) Highly cooperative DNA binding by the coliphage HKO22 repressor. J Mol Biol 230: 1108-1130.

Carlson, N.G., and Little, J.W. (1993b) A novel antivirulence element in the temperate bacteriophage HK022. J Bacteriol 175: 7541-7549.

Court, D., and Sato, K. (1969) Studies of novel transducing variants of lambda: dispensability of genes $\mathrm{N}$ and $\mathrm{Q}$. Virology 39: 348-352.

Crawford, J.A., Kaper, J.B., and DiRita, V.J. (1998) Analysis of ToxR-dependent transcription activation of ompU, the gene encoding a major envelope protein in Vibrio cholerae. Mol Microbiol 29: 235-246.

Flashman, S.M. (1978) Mutational analysis of the operators of bacteriophage lambda. Mol Gen Genet 166: 61-73.

Fong, R.S., Woody, S., and Gussin, G.N. (1993) Modulation of $P(R M)$ activity by the lambda $p R$ promoter in both the presence and absence of repressor. $J$ Mol Biol 232: 792-804.

Fowler, R.G., Degnen, G.E., and Cox, E.C. (1974) Mutational specificity of a conditional Escherichia coli mutator, mutD5. Mol Gen Genet 133: 179-191.

Friedman, D.I., Olson, E.J., Carver, D., and Gellert, M. (1984) Synergistic effect of himA and gyrB mutations: evidence that him functions control expression of $i l v$ and $x y l$ genes. $J$ Bacteriol 157: 484-489.

Gussin, G.N., Johnson, A.D., Pabo, C.O., and Sauer, R.T. (1983) Repressor and Cro protein: structure, function, and role in lysogenization. In Lambda II. Hendrix, R.W., Roberts, J.W.,Stahl, F.W., and Weisberg, R.A. (eds). Cold Spring Harbor, NY: Cold Spring Harbor Press, pp. 93-121.

Hershberger, P.A., and deHaseth, P.L. (1991) RNA polymerase bound to the $\mathrm{pR}$ promoter of bacteriophage lambda inhibits open complex formation at the divergently transcribed PRM promoter. Implications for an indirect mechanism of transcriptional activation by lambda repressor. J Mol Biol 222: 479-494.

Hochschild, A., Irwin, N., and Ptashne, M. (1983) Repressor structure and the mechanism of positive control. Cell 32 : 319-325.

Hopkins, N., and Ptashne, M. (1971) Genetics of virulence. In The Bacteriophage Lambda. Hershey, A.D., (ed.). Cold Spring Harbor, NY: Cold Spring Harbor Laboratory, pp. 571-574.

Horton, R.M., Cai, Z.L., Ho, S.N., and Pease, L.R. (1990) Gene splicing by overlap extension: tailor-made genes 
using the polymerase chain reaction. Biotechniques 8: 528-535.

Huang, A., Friesen, J., and Brunton, J.L. (1987) Characterization of a bacteriophage that carries the genes for production of Shiga-like toxin I in Escherichia coli. J Bacteriol 169: 4308-4312.

Jacob, F., and Wollman, E.L. (1954) Etude génétique d'un bactériophage tempéré d'Escherichia coli I L système génétique du bactériophage $\lambda$. Ann Inst Pasteur 85: 653-673.

Johnson, A.D., Poteete, A.R., Lauer, G., Sauer, R.T., Ackers, G.K., and Ptashne, M. (1981) lambda Repressor and cro components of an efficient molecular switch. Nature 294: 217-223.

Juhala, R.J., Ford, M.E., Duda, R.L., Youlton, A., Hatfull, G.F., and Hendrix, R.W. (2000) Genomic sequences of bacteriophages HK97 and HK022: Pervasive mosaicism in the Lambdoid phages. J Mol Biol 299: 27-51.

Kaper, J.B., and O'Brien, A.D. (1998) Escherichia coli O157: $\mathrm{H} 7$ and Other Shiga Toxin Producing E. coli strains. Washington, DC: American Society for Microbiology.

Karch, H., Schmidt, H., Janetzki-Mittmann, C., Scheef, J., and Kroger, M. (1999) Shiga toxins even when different are encoded at identical positions in the genomes of related temperate bacteriophages. Mol Gen Genet 262: 600-607.

Kimmitt, P.T., Harwood, C.R., and Barer, M.R. (1999) Induction of type 2 Shiga toxin synthesis in Escherichia coli 0157 by 4-quinolones. Lancet 353: 1588-1589.

Koudelka, G.B., and Lam, C.Y. (1993) Differential recognition of OR1 and OR3 by bacteriophage 434 repressor and Cro. J Biol Chem 268: 23812-23817.

Little, J.W. (1995) The SOS regulatory system. In Regulation of Gene Expression in Escherichia Coli. Linn, E.C.C., and Lynch, A.S. (eds). Georgetown, TX: R.G. Landis, pp. 453-479.

Matsushiro, A., Sato, K., Miyamoto, H., Yamamura, T., and Honda, T. (1999) Induction of prophages of enterohemorrhagic Escherichia coli O157: H7 with norfloxacin. J Bacteriol 181: 2257-2260.

Miller, H.I., and Friedman, D.I. (1980) An E. coli gene product required for lambda site-specific recombination. Cell 20: 711-719.

Mizutani, S., Nakazono, N., and Sugino, Y. (1999) The socalled chromosomal verotoxin genes are actually carried by defective prophages. DNA Res 6: 141-143.

Mozola, M.A., Friedman, D.I., Crawford, C.L., Wulff, D.L., Shimatake, H., and Rosenberg, M. (1979) Mutations reducing the activity of $c 17$, a promoter of phage lambda formed by a tandem duplication. Proc Natl Acad Sci USA 76: $1122-1125$.

Murphy, K.C. (1998) Use of bacteriophage lambda recombination functions to promote gene replacement in Escherichia coli. J Bacteriol 180: 2063-2071.

Neely, M.N., and Friedman, D.I. (1998a) Arrangement and functional identification of genes in the regulatory region of lambdoid phage $\mathrm{H}-19 \mathrm{~B}$, a carrier of a Shiga-like toxin. Gene 223: $105-113$.

Neely, M.N., and Friedman, D.I. (1998b) Functional and genetic analysis of regulatory regions of coliphage $\mathrm{H}-19 \mathrm{~B}$ : location of shiga-like toxin and lysis genes suggest a role for phage functions in toxin release. Mol Microbiol 28: 1255-1267.

O'Brien, A.D., and Holmes, R.K. (1987) Shiga and Shiga-like toxins. Microbiol Rev 51: 206-220.

O'Brien, A.D., and Holmes, R.K. (1996) Protein toxins of Escherichia coli and Salmonella. In Escherichia Coli and Salmonella: Cellular and Molecular Biology. Neidhardt, F.C. (ed.). Washington, D.C: American Society for Microbiology Press, pp. 2788-2802.

O'Brien, A.D., Newland, J.W., Miller, S.F., Holmes, R.K., Smith, H.W., and Formal, S.B. (1984) Shiga-like toxinconverting phages from Escherichia coli strains that cause hemorrhagic colitis or infantile diarrhea. Science 226: 694-696.

Ogawa, T., Masukata, H., and Tomizawa, J. (1988) Transcriptional regulation of early functions of bacteriophage phi 80. J Mol Biol 202: 551-563.

Plunkett, G., III, Rose, D.J., Durfee, T.J., and Blattner, F.R. (1999) Sequence of Shiga toxin 2 phage 933W from Escherichia coli O157: H7: Shiga toxin as a phage lategene product. J Bacteriol 181: 1767-1778.

Poteete, A.R., Ptashne, M., Ballivet, M., and Eisen, H. (1980) Operator sequences of bacteriophages P22 and 21. J Mol Biol 137: 81-91.

Ptashne, M. (1971) Repressor and its action. In The Bacteriophage Lambda. Hershey, A.D. (ed.). Cold Spring Harbor, NY: Cold Spring Harbor Laboratory, pp. 221-237.

Ptashne, M. (1992) A Genetic Switch, 2nd Edn. Cambridge, MA: Cell Press.

Ptashne, M., Jeffrey, A., Johnson, A.D., Maurer, R., Meyer, B.J., Pabo, C.O., Roberts, T.M., and Sauer, R.T. (1980) How the lambda repressor and cro work. Cell 19: 1-11.

Roberts, J. (1992) Antitermination and the control of transcription elongation. In Transcription Regulation. McKnight, S.L., and Yamamoto, K.R., (eds). Cold Spring Harbor, NY: Cold Spring Harbor Laboratory, pp. 389-406.

Roberts, J.W., Yarnell, W., Bartlett, E., Guo, J., Marr, M., Ko, D.C., Sun, H., and Roberts, C.W. (1998) Antitermination by bacteriophage Lambda $Q$ protein. Cold Spring Harbor Symposium Quant. Biol. LXIII: 319-325.

Sly, W.S., Rabideau, K., and Kolber, A. (1971) The Mechanism of Lambda Virulence: II Regulatory mutations in classical virulence. In The Bacteriophage Lambda. Hershey, A.D. (ed.). Cold Spring Harbor, NY: Cold Spring Harbor Laboratory, pp. 575-588.

Strainic, M.G. Jr, Sullivan, J.J., Collado-Vides, J., and deHaseth, P.L. (2000) Promoter interference in a bacteriophage lambda control region: effects of a range of interpromoter distances. J Bacteriol 182: 216-220.

Susskind, M.M., and Botstein, D. (1978) Molecular genetics of bacteriophage P22. Microbiol Rev 42: 385-413.

Unkmeir, A.and.Schmidt, H. (2000) Structural analysis of phage-borne stx genes and their flanking sequences in shiga toxin-producing Escherichia coli and Shigella dysenteriae type 1 strains. Infect Immun 68: 4856-4864.

Wagner, P.L., Neely, M.N., Zhang, X., Acheson, D.W.K., Waldor, M.K., Friedman, D.I. (2001) Role for a phage promoter in shiga toxin, 2 expression from a pathogenic Escherichia coli. J. Bacteriol 183: 2081-2085.

Waldor, M.K. (1998) Bacteriophage biology and bacterial virulence. Trends Microbiol 6: 295-297. 
Weisberg, R.A., Gottesman, M.E., Hendrix, R.W., and Little, J.W. (1999) Family values in the age of genomics: Comparative analysis of temperate bacteriophage HKO22. Ann Rev Genet 33: 565-602.

Weisberg, R.A., and Landy, A. (1983) Site-specific recombination in phage Lambda. In Lambda /I Hendrix, R.W., Roberts, J.W., Stahl, F.W., and Weisberg, R.A. (eds.). Cold Spring Harbor, NY: Cold Spring Harbor Laboratory, pp. 211-250.

Wharton, R.P., Brown, E.L., and Ptashne, M. (1984) Substituting an alpha-helix switches the sequence-specific DNA interactions of a repressor. Cell 38: 361-369.

$\mathrm{Xu}$, J., and Koudelka, G.B. (2000) Mutually exclusive utilization of $\mathrm{P}_{\mathrm{R}}$ and $\mathrm{P}_{\mathrm{RM}}$ promoters in bacteriophage 434 $\mathrm{O}_{\mathrm{R} .}$ J Bacteriol 182: 3165-3174.
Yu, D., Ellis, H.M., Lee, E.C., Jenkins, N.A., Copeland, N.G., and Court, D.L. (2000) An efficient recombination system for chromosome engineering in Escherichia coli. Proc Natl Acad Sci USA 97: 5978-5983..

Yu, R.R., and DiRita, V.J. (1999) Analysis of an autoregulatory loop controlling ToxT, cholera toxin, and toxincoregulated pilus production in Vibrio cholerae. J Bacteriol 181: 2584-2592.

Zhang, X., McDaniel, A.D., Wolf, L.E., Keusch, G.T., Waldor, M.K., and Acheson, D.W. (2000) Quinolone antibiotics induce Shiga toxin-encoding bacteriophages, toxin production, and death in mice. $J$ Infect Dis 181: 664-670.

Zhou, Y.H., Zhang, X.P., and Ebright, R.H. (1991) Random mutagenesis of gene-sized DNA molecules by use of PCR with Taq DNA polymerase. Nucleic Acids Res 19: 6052. 